
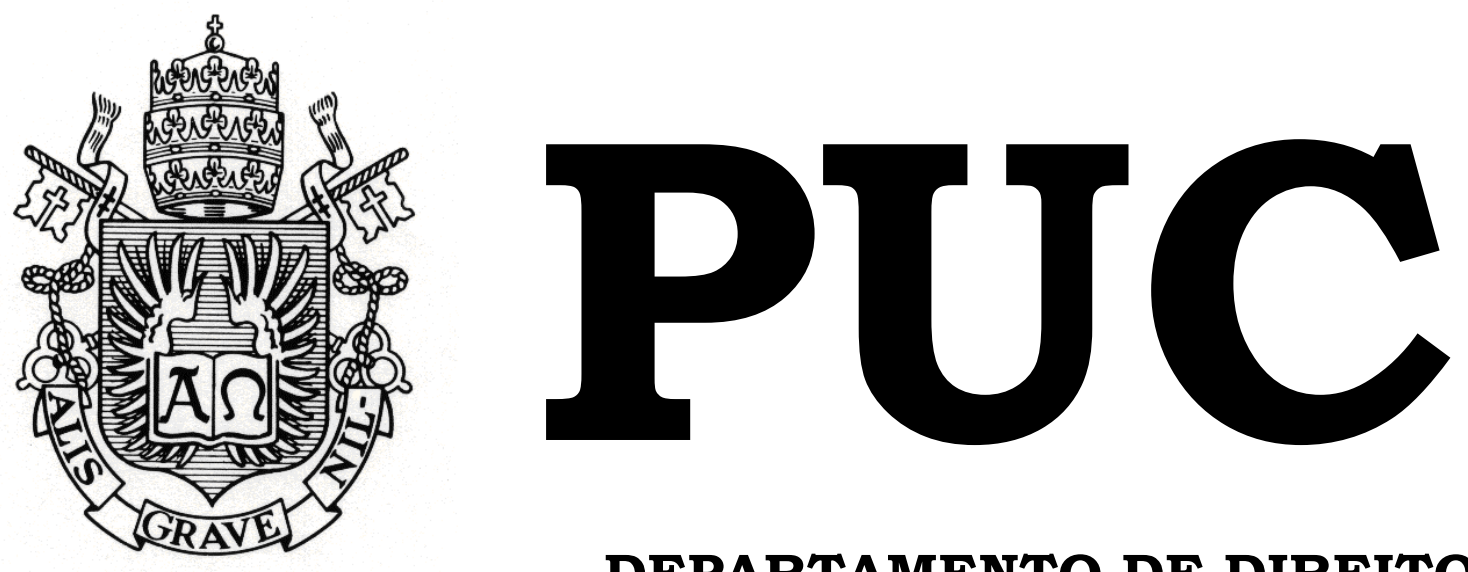

DEPARTAMENTO DE DIREITO

\title{
OS EFEITOS DA TRIBUTAÇÃO NA ORDEM ECONÔMICA: UMA ANÁLISE CONCORRENCIAL
}

\author{
por \\ AMANDA ALBANO SOUZA DA SILVA
}

ORIENTADOR: Luiz Emygdio Franco da Rosa Júnior

CO-ORIENTADOR: Pedro Marcos Nunes Barbosa

2017.2

PONTIFÍCIA UNIVERSIDADE CATÓLICA DO RIO DE JANEIRO

RUA MARQUÊS DE SÃO VICENTE, 225 - CEP 22453-900 RIO DE JANEIRO - BRASIL 


\title{
OS EFEITOS DA TRIBUTAÇÃO NA ORDEM ECONÔMICA: UMA ANÁLISE CONCORRENCIAL
}

\author{
por \\ AMANDA ALBANO SOUZA DA SILVA
}

Monografia apresentada ao Departamento de Direito da Pontifícia Universidade Católica do Rio de Janeiro (PUC-Rio) para a obtenção do Título de Bacharel em Direito.

Orientador: Luiz Emygdio Franco da Rosa Júnior

Co-Orientador: Pedro Marcos Nunes Barbosa 


\section{DEDICATÓRIA}

Aos meus queridos pais, Albano e Wilma, que sempre me incentivaram e propiciaram a realização deste trabalho. 


\section{AGRADECIMENTOS}

Ao meu querido pai e amigo, Albano Pimenta, pela influencia e todos os ensinamentos que ultrapassam a mera academia e são essenciais à minha formação.

À minha adorável mãe, Wilma Nóbrega, pela amizade, suporte, e incentivo.

Aos orientadores, Luiz Emygdio Franco da Rosa Júnior e Pedro Marcos Nunes Barbosa, pelo auxílio na jornada acadêmica.

Aos professores, por repartirem seus conhecimentos de maneira tão inspiradora, em especial: Rachel Barros Nigro, Ana Lúcia de Lyra Tavares, Regina Coeli Lisboa Soares, Flávia da Costa Limmer, Inês Alegria Rocumback e William Takachi. 


\section{RESUMO}

O presente trabalho pretende analisar quais os efeitos da tributação na ordem econômica sob uma perspectiva concorrencial, isto é, entender em que medida a carga tributária impacta no mercado de modo a estimular ou distorcer comportamentos e atingir a concorrência. Nestes moldes buscarse-à estabelecer pontos de contato entre o direito tributário e o direito concorrencial, tendo por base a doutrina mais recente compreendendo este como instrumento de implementação de políticas públicas.

Palavras-Chave: Tributação. Concorrência. Ordem Econômica. Livre Iniciativa. Livre Concorrência. Neutralidade Tributária. Planejamento Tributário. Guerra Fiscal. 


\section{SUMÁRIO}

DEDICATÓRIA 2

AGRADECIMENTOS

RESUMO 4

SUMÁRIO 5

ABREVIAÇÕES E SIGLAS

INTRODUÇÃO

CAPÍTULO I. Ordem Econômica 9

CAPÍTULO II. Direito Concorrencial como Implementação de Políticas Públicas $\quad 14$

II.1 Sistema Brasileiro de Defesa da Concorrência 19

CAPÍTULO III. Poder de Tributar $\quad 22$

CAPÍTULO IV. Utopia da Neutralidade Tributária 27

CAPÍTULO V. Custos da Tributação ao Mercado 31

CAPÍTULO VI. Guerra Fiscal, Incentivos e Benefícios 40

CAPÍTULO VII. Tributação e Concorrência no CADE 45

CONCLUSÃO $\quad 50$

BIBLIOGRAFIA 


\section{ABREVIAÇÕES E SIGLAS}

ADCT - Atos das Disposições Constitucionais Transitórias

ART. - Artigo

ICMS - Imposto sobre Circulação de Mercadorias e Serviços

IE - Imposto sobre Exportação

II ～- Imposto sobre Importação

IOF - Imposto sobre Operações Financeiras

IPTU - Imposto Predial Territorial Urbano

ITR - Imposto Territorial Rural

CADE - Conselho Administrativo de Defesa Econômica

CF - Constituição Federal da República Federativa do Brasil de 1988

CTN - Código Tributário Nacional

SBDC - Sistema Brasileiro de Defesa da Concorrência

SEAE - Secretaria de Acompanhamento Econômico do Ministério da

Fazenda

STF - Supremo Tribunal Federal 


\section{INTRODUÇÃO}

Se por um lado tem-se que os tributos são inegavelmente essenciais ao funcionamento da máquina pública, por outro há de se ponderar os efeitos por eles produzidos. Isto é, faz-se necessário valorar de que modo a tributação impacta o mercado, seja estimulando-o ou distorcendo-o. Do mesmo modo, é preciso entender de que maneira a tributação e a defesa da concorrência estão atreladas à função estatal de implementar políticas públicas.

Nesse sentido, imperioso verificar como os custos da tributação sobre a atividade produtiva podem afetar a concorrência e de que maneira isso influencia a alocação de recursos.

Assim, pretende-se afirmar a utopia da neutralidade tributaria sobre o mercado e entender a tributação como fator verificável na tomada de decisão dos players. E, consequentemente questionar até que ponto a receita auferida mediante a arrecadação fiscal é mais benéfica ao interesse público, ou seja, se a alteração comportamental derivada da tributação representa impacto mais gravoso ao bem estar social que os possíveis benefícios atrelados a receita tributária.

Para tanto será analisado o conceito de ordem econômica, percorrendo como esta surgiu nas Constituições brasileiras e qual sua expressão na Constituição Federal de 1988, seguido de breve histórico do direito concorrencial, compreendendo os atuais mecanismos dispostos pelo Sistema Brasileiro de Defesa da Concorrência - estruturado na Lei 12.529 de 30 de novembro de 2011 .

Em sequencia ter-se-à a verificação de como o poder de tributar representa custos ao mercado, negando-se a possibilidade de uma neutralidade tributária e especificamente de que maneira o planejamento tributário pode auxiliar o contribuinte na adoção do caminho menos 
oneroso - tributariamente - sem que para tanto adentre-se aos liames ilícitos. Do mesmo modo, tecer-se-à breves considerações sobre a guerra fiscal e dos benefícios e incentivos fiscais como sua configuração pode caracterizar pratica anticompetitiva, revelando-se potenciais fatores de distorção da concorrência.

Por fim, serão analisadas algumas decisões do Conselho Administrativo de Defesa Econômica em que a tributação aparece atrelada à violação da concorrência. 


\section{CAPÍTULO I}

\section{Ordem Econômica}

A ordem econômica é expressão que pode, dentre seus diversos significados, designar tanto: (i) a ordem fática concreta composta pelas relações econômicas; (ii) como o mundo do dever-ser, refletindo as disposições regulatórias dos fenômenos econômicos e ainda, há de se falar na (iii) concepção de ordem econômica como sinônimo de ordem jurídica. Vital Moreira, renomado jurista português, em sua obra intitulada A Ordem Jurídica do Capitalismo, além de demonstrar a relação entre a ordem jurídica e a ordem econômica ${ }^{1}$ e da ausência de sobreposição entre elas, traz relevantes considerações sobre as possíveis definições atribuíveis à “expressão polissémica" que é a "ordem econômica":

"O primeiro tem com objecto $<<$ o conjunto das formas nas quais se realiza in concreto a direcção do processo económico cotidiano $>>, 2$ isto é, $<<$ o modo de ser empírico de uma determinada economia concreta $>>3$. O que caracteriza este conceito é o facto de referir-se, não a um conjunto de regras ou normas reguladoras de relações sociais, mas sim a uma relação entre fenómenos económicos materiais, uma relação entre factores económicos concretos, ou uma concreta estrutura de sujeitos e unidades económicos ${ }^{4}$.

(...)

Num outro sentido, a ser encontrado principalmente na literatura económica, o termo designa o conjunto de todas as normas ou regras de conduta, qualquer que seja a sua natureza: jurídica, religiosa, moral, etc., que se reclamam a regulação do comportamento dos sujeitos económicos. É o sistema normativo (no sentido da sociologia) da acção económica55.

(...)

Num terceiro sentido, ordem económica significa, pura e simplesmente, ordem

\footnotetext{
1 "Na realidade, se algo pode ser firmado desde já é que as formas económicas e as formas jurídicas não se recobrem totalmente. A ordem jurídica não reflecte ponto por ponto a estrutura económica. A estrutura económica é sem duvida $<<$ traduzida $>>$ em ordem jurídica, mas é-o em termos jurídicos ( : juridicamente)." MOREIRA, Vital. A ordem jurídica do capitalismo. Coimbra: Centelha. 1973.p. 13
}

2 Ibid.p. 68 Nota n $^{\circ} 1$ do Original - EUCKEN (1) 167, (3) 515

${ }^{3}$ Ibid. p. 68 Nota $^{\circ} 2$ do Original - BADURA (1) 289, nota 25; no mesmo sentido M. WEBER (1) 368 e CHENOT (3) 4.

4 Ibid. p. 68 Nota $\mathrm{n}^{\mathrm{o}} 3$ do Original CF KARSTEN 135 SCHNEIDER I 18 ss. Sobre a noção de $<$ agente $>$ e $<$ unidade $>$ económicos, Grossman 13.

5 Ibid. p. 69 Nota $n^{\circ} 6$ do Original: Assim Sombart: < conjunto de todas as normas ou princípios que determinam a acção dos sujeitos económicos>; Paulsen: <conjunto de normas [reguladoras] da conduta económica, cuja vigência é assegurada pelo direito, pela religião, pela moral, etc.> (citados por Karsten 129 s). 
jurídica da economia, sendo construída pelo conjunto de regras jurídicas que regulam a vida económica, isto é, aquelas que, num determinado espaço económico, têm por objecto as relações de produção e, em geral, as relações económicas que têm lugar nesse espaço. 67

Desse modo, utilizar-se-à a expressão ordem econômica nos primeiro e terceiro sentidos atribuídos ao termo. Assim, como conceito de fato que reflete o conjunto das relações econômicas in concreto quando se fizer referência às repercussões da tributação na tomada de decisão pelos agentes do mercado e como ordem jurídica da economia ao se tratar da regulação estatal sobre a atividade econômica.

Além da abordagem conceitual deve-se demonstrar como a Ordem Econômica surge nas constituições brasileiras ${ }^{8}$. Iniciada sua aparição na Constituição de 1934 a ordem econômica surge atrelada à ordem social ${ }^{9} \mathrm{e}$ assim se mantém até a de 198810, excepcionada a de 1937 - a qual conta com capitulo exclusivamente destinado a ordem econômica. No decorrer das constituições a ordem econômica foi pautada no mundo do dever ser

\footnotetext{
6 Ibid. p. 70 Nota $n^{\circ} 9$ do Original: Assim, E. Stein (1) 30, nota 1; Böhm: <totalidade dos princípios e instituições jurídicos que determinam a actividade económica de todos os participantes numa economia de divisão de trabalho> (citado por Zacher 74, nota 56).

${ }^{7}$ Ibid p. $67-71$

8 Vital Moreira já em suas considerações introdutórias nos revela essa metodologia ao passo que defende a analise da ordem jurídica do capitalismo em dois planos, quais sejam: “(...) num plano geral, isto é, em todos os aspectos juridicamente relevantes da economia; e num plano constitucional, isto é, naqueles aspectos fundamentais da ordem jurídico-económica e que, por isso, estão mais ou menos completamente incluídos na constituição do estado.” Ibid. p.14

${ }^{9}$ Sobre a terminologia adotada nas constituições 'da ordem econômica e social' cabe destacar a critica de Eros Roberto Grau: "Tanto antes com agora, no entanto, a alusão a uma e a outra, além de injustificada, conduz a ambiguidades. De um parte, a uma ordem social (seja econômica e social vou tão somente social) como subconjunto de normas constitucionais poderia nos levar a indagar do caráter das demais normas constitucionais - não teriam elas, acaso, também caráter social? O fato é que toda a ordem jurídica é social, na medida em que voltada à ordenação social. Ademais, poder-se-ia mesmo tudo inverter, desde a observação de que a ordem social -ordem normativa, da sociedade - abrange, além da ordem jurídica positiva, uma ordem ética, inúmeras ordens religiosas e diversas ordens jurídicas não "positivadas"." GRAU, Eros Roberto. Op. Cit. p. 69

10 "Todas as Constituições brasileiras posteriores passaram a incluir um capítulo sobre a Ordem Econômica e Social, em que se tratava da intervenção do Estado na economia e dos direitos trabalhistas. A primeira a romper com essa sistemática foi a Constituição de 1988, ao incluir os direitos trabalhistas em capítulo diverso ao dos Direitos Sociais."BERCOVICI, Gilberto. Constituição econômica e desenvolvimento : uma leitura a partir da Constituição de 1988. São Paulo: Malheiros, 2005. p.18
} 
por princípios e orientações próprias de cada época. Abrangeu-se desde "princípios da justiça e necessidades da vida nacional”11 a fim de assegurar existência digna, fomento da econômica popular, o desenvolvimento do credito, e a nacionalização de determinados setores $^{12}$, passando pela valorização do trabalho como dever social, a prosperidade nacional, manutenção do fomento da economia popular e da nacionalização Constituição de 1937 - até a justiça social combinada com a liberdade de iniciativa, valorização do trabalho e a busca pela garantia a existência digna - Constituição de 1946.

A Constituição da República Federativa do Brasil de 1988 conta com título próprio destinado à ordem econômica e financeira, compreendendo os artigos 170 a 192, e revela a ordem econômica como implementadora de políticas públicas. Esta função ultrapassa o papel intermediário do Estado, afastando-o da figura meramente mediadora e organizadora, passando a exigir uma atuação proativa na concretização dos fundamentos (art. $1^{\circ} \mathrm{CF} /$ 88) $)^{13}$ e objetivos (art. $\left.3^{\circ} \mathrm{CF} / 88\right)^{14}$ da República traçando diretrizes a fim de ensejar a aplicabilidade e interpretação dinâmicas da própria constituição.

Nesse sentido dispõe Eros Roberto Grau:

11 Constituição de 1934 : “Art 115 - A ordem econômica deve ser organizada conforme os princípios da Justiça e as necessidades da vida nacional, de modo que possibilite a todos existência digna. Dentro desses limites, é garantida a liberdade econômica."

12 Constituição de 1934: “Art 117 - A lei promoverá o fomento da economia popular, o desenvolvimento do crédito e a nacionalização progressiva dos bancos de depósito. Igualmente providenciará sobre a nacionalização das empresas de seguros em todas as suas modalidades, devendo constituir-se em sociedades brasileiras as estrangeiras que atualmente operam no País."

13 “Art. $1^{\circ}$ A República Federativa do Brasil, formada pela união indissolúvel dos Estados e Municípios e do Distrito Federal, constitui-se em Estado Democrático de Direito e tem como fundamentos: I - a soberania; II - a cidadania; III - a dignidade da pessoa humana; IV - os valores sociais do trabalho e da livre iniciativa; V - o pluralismo político."

14 “Art. $3^{\circ}$ Constituem objetivos fundamentais da República Federativa do Brasil: I - construir uma sociedade livre, justa e solidária; II - garantir o desenvolvimento nacional; III - erradicar a pobreza e a marginalização e reduzir as desigualdades sociais e regionais; IV - promover o bem de todos, sem preconceitos de origem, raça, sexo, cor, idade e quaisquer outras formas de discriminação." 
"A contemplação, nas nossas Constituições, de um conjunto de normas compreensivo de uma "ordem econômica", ainda que como tal não formalmente referido, é expressiva de marcante transformação que afeta o direito, operada no momento em que deixa de meramente prestar-se à harmonização de conflitos e à legitimação do poder, passando a funcionar como instrumento de implementação de políticas (no que, de resto, opera-se o reforço da função de legitimação do poder)."15

\section{(...)}

"A ordem econômica (mundo do dever ser) produzida pela Constituição de 1988 consubstancia um meio para a construção do Estado Democrático de Direito que, segundo o art. $1^{\circ}$ do texto, o Brasil constitui. Não o afirma como Estado de Direito Social - é certo - mas a consagração dos princípios da participação e da soberania popular, associada ao quanto se depreende da interpretação, no contexto funcional, da totalidade dos princípios que a conformam (a ordem econômica), aponta no sentido dele.

A inexistência de contradição entre tais princípios, a textura das regras constitucionais consideradas e, ainda, a atribuição, à sociedade, de legitimidade para reivindicar a realização de políticas públicas podem fazer do Estado efetivo agente - por ela responsável- da promoção do bemestar." 16

Dessa forma, a atual Constituição orienta a atuação estatal de modo a garantir não só direitos atrelados a proteção do sistema, mas a reivindicar a efetividade de implementação de políticas públicas. ${ }^{17}$

Demonstrando a sua força normativa ${ }^{18}$ e condicionando-se à

\footnotetext{
15 GRAU, Eros Roberto. Op.cit. p.15

16 Ibid. p.316

17 "No desempenho do seu novo papel, o Estado, ao atuar como agente de implementação de políticas públicas, enriquece suas funções de integração, de modernização e de legitimação capitalista. Esse sua atuação, contudo, não conduz á substituição do sistema capitalista por outro. Pois é justamente a fim de impedir tal substituição - seja pela via da transição para o socialismo que o Estado é chamado a atuar sobre e no domínio econômico. O sistema capitalista é assim preservado, renovado sob diverso regime. O modo de produção. Os esquemas de repartição do produto e os mercados capitalistas, no âmbito interno e no quadro internacional, são mantidos em sua integridade. Daí porque interessa ao capitalismo uma Constituição "progressista". Justamente no ser "progressiva" é que a Constituição formal não apenas ensejará a manutenção da "ordem capitalista", mas conferirá operacionalidade plena ao poder detido pela classes dominantes." Ibid.p. 43
}

18 HESSE, K. A FORÇA NORMATIVA DA CONSTITUIÇÃO. Traduzido por: Gilmar Ferreira Mendes. Porto Alegre: safE. 
realidade fática ${ }^{19}$, supera-se a afirmação de papel acessório, quiçá inexistente, consubstanciando mera folha de papel $^{20}$. Tem-se a inclinação e a exigência por uma interpretação dinâmica 21 que permita a reconstrução do texto junto ao fato jurídico e relevante 22 viabilizando a função de implementar políticas públicas pari passu a aplicabilidade/concretização de sua carga principiológica ${ }^{23}$.

\begin{abstract}
19 Nesse sentido, afirma-se a Constituição como norma jurídica cuja representação não configura mero espelho ou sustento dos fatores reais de poder, mas sim é capaz de exercer papel determinante na realidade social. Isto é, configura via de mão dupla ao passo que: "Determinada pela realidade social e, ao mesmo tempo, determinante em relação a ela, não se pode definir como fundamental nem a pura normatividade, nem a simples eficácia das condições sócio-políticas econômicas." HESSE, Konrad. Op. Cit.. p. 15. Além disso, tal normatividade de que é dotada a Constituição vem acompanhada não só de certa correspondência à realidade, mas também da vontade de Constituição.
\end{abstract}

20 LASSALE, Ferdinand. QUE É UMA CONSTITUIÇÃO?. Traduzido por: Walter Stönner. São Paulo: Edições e Publicações Brasil, 1993.

21 "Constituição dirigente que é, a de 1988 reclama - e não apenas autoriza - interpretação dinâmica. Volta-se à transformação da sociedade, transformação que será promovida na medida em que se reconheça, no art. $3^{\circ}$ - e isso se impõe -, fundamento à reivindicação, pela sociedade, de direito à realização de políticas públicas. Políticas públicas que, objeto de reivindicação constitucionalmente legitimada, hão de importar o fornecimento de prestações positivas à sociedade." GRAU, Eros Roberto. Op.cit. p.212

22 Neste ponto cabe fazer uma diferenciação que será de tanto útil para compreensão de algumas colocações, no que tange o papel do magistrado e a necessidade de atividade criativa vinculada ao texto normativo. Em suma: entende-se o texto normativo como a letra da lei, isto é, a disposição legal; ao passo que a norma jurídica vai além, representando o texto normativo interpretado/ aplicado à realidade, ao caso concreto. Basicamente: distinguem-se norma e texto normativo vez que, valorizando o trabalho interpretativo e judicial, sendo a norma resultado do processo de concretização do direito, da atividade jurisdicional e, ao mesmo tempo, um movimento de (re)construção. Em suma, a norma é a conjunção do direito e realidade. Sobre a matéria: MÜLLER, F. O NOVO PARADIGMA DO DIREITO Introdução à teoria e metódica estruturantes. 3a ed.rev.at.amp. Tradução de Peter Naumann, Eurides Avance de Souza. São Paulo: Editora Revista dos Tribunais, 2013. 272p.

${ }^{23}$ Especificamente no que tange ao direito concorrencial: "Art. 170. A ordem econômica, fundada na valorização do trabalho humano e na livre iniciativa, tem por fim assegurar a todos existência digna, conforme os ditames da justiça social, observados os seguintes princípios: I - soberania nacional; II - propriedade privada; III - função social da propriedade; IV - livre concorrência; V defesa do consumidor; VI - defesa do meio ambiente, inclusive mediante tratamento diferenciado conforme o impacto ambiental dos produtos e serviços e de seus processos de elaboração e prestação; VII - redução das desigualdades regionais e sociais; VIII - busca do pleno emprego; IX - tratamento favorecido para as empresas de pequeno porte constituídas sob as leis brasileiras e que tenham sua sede e administração no País." 


\section{CAPÍTULO II}

\section{Direito Concorrencial como Implementação de Políticas}

\section{Públicas}

O Direito concorrencial pode ser entendido como regramento jurídico que tem por finalidade a proteção da sistema concorrencial, intervindo o Estado de modo a garantir não a mera proteção dos agentes, mas algo maior, a própria concorrência. Nesse sentido, a concorrência é vista como valor em si, e objeto da proteção estatal de modo que tem-se uma finalidade última que ultrapassa a mera proteção seja do mercado ou do consumidor. Desse modo dispõe Calixto Salomão Filho:

"Consequentemente, a concorrência - e não o mercado - é o valor a ser protegido pelo direito concorrencial. A possibilidade de escolha de um valor social, que não pode ser negado e que deve ser necessariamente reconhecido pelo Direito. O mercado, por outro lado, não necessariamente leva a esse resultado. É aí que o Estado deve intervir, garantindo a primeira, e não o segundo"24

No entanto, tal enfoque mais ampliado é recente ${ }^{25}$, de modo que pode-se seguimentar o histórico do direito concorrencial em três grandes períodos, apresentando em cada um deles uma função estatal regulatória própria e contextualizada à época.

Primeiramente, o direito concorrencial surge com a finalidade de estabelecer regras de conduta como forma de organização mercadológica. $\mathrm{Na}$ antiguidade grega, por exemplo, aparece a regulamentação dos monopólios como forma de aferir receita pública, e evitar-se a manipulação

\footnotetext{
24 SAlOMÃo FILHO, Calixto. Direito Concorrencial - As Condutas. 1a ed. 2a tiragem. São Paulo: Malheiros, 2007.p. 50

25 “O primeiro passo lógico para a correta definição do conceito de concorrência é distinguir a proteção da concorrência da proteção do concorrente.

Hoje está bem reconhecida a distinção entre os dois conceitos, e admitido o fato de que tanto concorrentes tanto consumidores são tutelados pelo direito de concorrência indiretamente, através da ordem concorrencial (v. infra, itens 3.2 e 3.3). Mas nem sempre foi assim. $O$ direito concorrencial fez um longo percurso histórico até se livrar da concepção privatista que via na proteção ao concorrente a forma de tutelar a concorrência." Ibid. p.52
} 
de preços e oferta de produtos. ${ }^{26}$ Enquanto que na antiguidade romana, mantém-se a preocupação com o abuso de preços, é trazida a vedação ao açambarcamento de mercadorias e, percebe-se a movimentação espontânea do mercado a fim de determinar regras comportamentais capazes de possibilitarem uma legitima expectativa da contraparte. Sucessivamente, na Idade Média, tem-se os monopólios atrelados aos privilégios dos nobres, e surge a figura das corporações de ofício, associações de trabalhadores autônomos que suprimiam a concorrência, estabelecendo um agrupamento e predeterminação do nicho mercadológico ${ }^{27}$. Basicamente tem-se que o objetivo principal do direito concorrencial nesse primeiro momento é a proteção da população e da economia imediata, almejando-se a obtenção de resultados efetivos. Conjuntamente, há a tendência em criar-se expectativas e previsibilidade pelos agentes na condução de seus negócios. Previsibilidade que é intrínseca e própria à noção de mercado, isto é:

"O mercado, anota ainda Irti, é uma ordem, no sentido de regularidade e previsibilidade de comportamentos, cujo funcionamento pressupõe a obediência, pelos agentes que nele atuam, de determinadas condutas." 28

Em um segundo período, já na Revolução Industrial, a concorrência aparece, ao lado do liberalismo econômico, como instrumento residual de controle estatal com objetivo de proteger o mercado dos efeitos destrutíveis de seus agentes, isto é: da autofagia do sistema. Imperando a livre concorrência atribui-se ao Estado um papel secundário na atuação no mercado assegurando a livre competição, cabendo-lhe a função de

\footnotetext{
26 FORGIONI, Paula A. Op.cit. p.39

27 "Essas normas que se vai colocando, correlatas ao monopólio das corporações, tangenciam problemas de acesso ao mercado e limitam a liberdade de concorrência de cada um. As corporações de oficio impunham barreiras, controlando o acesso ao mercado dos agentes econômicos que ofereciam uma concorrencial potencial, detendo, portanto, o perfeito controle da oferta do produto no mercado." Ibid. p. 47
}

28 GRAU, Eros Roberto. Op. Cit. p.30 
mediador dos excessos, devendo deixar o mercado se auto regular. ${ }^{29}$ Configura-se assim, a máxima laissez faire, laissez passer que reflete a abstenção estatal na ordem econômica de modo, limitando-se a observa-lá e organizá-la. ${ }^{30}$

Ocorre que a percepção de que a autoregulação do mercado enseja crises cíclicas e com a passagem do liberalismo para o Estado de Bem Estar Social, exigiu-se uma atuação estatal que fosse além da mera dirigência / equilíbrio de instabilidades, transmudando-se o direito concorrencial em instrumento de que se vale o Estado para implementar políticas.

Neste terceiro e atual período é que o direito antitruste passa a ser reconhecido como verdadeira ferramenta de que faz (ou deve fazer) uso o Estado a fim de efetuar suas políticas públicas. Identifica-se a transição entre o papel do antitruste como mera proteção do mercado contra si mesmo, garantindo assim a sobrevivência ou perpetuação dos players, para a percepção de sua função implementar, buscando equilíbrio entre os núcleos de interesse envolvidos. Nesse sentido, Paula Forgioni:

"Temos, pois, um primeiro preconceito, que deverá ser abandonado. O antitruste já não pode ser visto apenas como arranjo inteligente de normas destinado a evitar ou neutralizar os efeitos autodestrutíveis do mercado liberal, mas, ao contrário, deve ser encarado como um instrumento de implementação de políticas públicas."’31

(...)

\footnotetext{
29 "A função primordial do Estado era a harmonização dos conflitos com o direito viabilizando a fluência das relações de mercado ("livre mercado"). FORGIONI, Paula A. Op. Cit. p. 60

30 "Partindo mais especificamente do Estado moderno, e a partir do final do século XVIII, vicejou nitidamente a supremacia da teoria do liberalismo econômico, divulgada e praticada graças à doutrina de ADAM SMITH, estampada em sua obra A riqueza das nações, de 1776. Por essa doutrina que, diga-se de passagem, atendia aos interesses da burguesia que passava a dominante, cada indivíduo deve ter liberdade de promover seus interesses, porque ninguém é melhor que ele para avaliá-los. Ao Estado não caberia a interferência nem a regulação da economia; limitava-se apenas a uma postura de mero observador da organização processada pelos indivíduos. O laissez faire, laissez passer dava bem a ideia da passividade do Estado diante dos fenômenos econômicos e sociais" CARVALHO FILHO, José dos Santos. Manual de direito administrativo - 28 ed.rev.,ampl. e atual. até 21-12-2014. São Paulo: Atlas, 2015. p. 943
} 
"No desempenho dessa nova função de direção da economia, o Estado utiliza instrumentos jurídicos que lhe permitem "estabilizar, estimular e dirigir o rumo de sua economia sem apelar para a ditadura e substituir um sistema baseado na propriedade por um sistema de poder ostensivo"32. Esses instrumentos inviabilização, mediante a direção do comportamento dos agentes econômicos, não apenas a preservação, mas a condução do mercado. Daí falar-mos em técnicas de direção sobre o mercado, de que utiliza o Estado em sua função de implementação de uma política pública" 33 .

Alberto Asquini em sua obra intitulada Perfis da Empresa demonstra que a depender do foco sob o qual seja analisado o conceito de empresa é possível identificar distintos perfis que lhe podem ser atribuídos. Em outras palavras, é possível, visto ser um conceito atinente a um fenômeno econômico poliédrico, captar a empresa de diferentes formas, entendendo-a em seu prisma: (i) subjetivo - materializando-se na figura do empresário e da sociedade empresária, isto é, aquele que exerce a atividade empresária; (ii) objetivo - referindo-se ao estabelecimento - bens corpóreos e incorpóreos que permitem o exercício da atividade; (iii) funcional - capta a empresa como atividade propriamente dita, ou seja: “(...) sob o ponto de vista funcional ou dinâmico, a empresa aparece como aquela força em movimento que é a atividade empresarial dirigia para um determinado escopo produtivo." 34 e (iv) corporativo - identificando a empresa como instituição, indo além da figura do empresário, partindo de um olhar interno, incluindo neste aspecto os empregados e colaboradores.

Posto isto, é possível traçar um paralelo entre a dita teoria poliédrica e a relação entre os núcleos de interesses que envolvem a implementação de políticas publicas. Basicamente, a função do Estado é implementar tais políticas públicas sob a matriz poliédrica, vez que se exige uma arquitetura

32 Ibid. p.78 "Nota do original n $n^{\circ}$ 165: Adolf Berle, The American economic republic, referido por Alberto Venâncio Filho, A intervenção do Estado no domínio econômico, p.12"

${ }^{33}$ Ibid. p. 78

34 ASQUINI, Alberto. Perfis da Empresa. Traduzido por: Fábio Konder Comparato. Revista de Direito Mercantil vol.104, out-dez/1996, p. 104 
jurídica que satisfaça as necessidades de todos os perfis, atendendo ao consumidor, Estado, mercado, meio ambiente, e ao trabalhador, de modo que se tenha de fato uma concorrência equilibrada. 35

O Estado passa a ter a incumbência de atuar em áreas essenciais não atrativas ao poder privado, bem como atuar exclusivamente naquelas searas que representem categórico interesse público/nacional ou envolvam a soberania nacional. Podendo ainda atuar no mercado sem privilégios ou garantias pela sua condição de ente público, agindo em igualdade com os players, ou em conjunto/parceria com estes. Além claro, de sua função regulatória própria, legislando e regulamentando o mercado, estabelecendo regras de conduta. Em suma: apresenta-se assim, uma atuação estatal multifacetada a medida que se conjuga a atuação (i) direta imperativa, (ii) por participação e (iii) regulatória.

Nesse sentido, demanda-se do Estado sua atuação nos pontos atinentes às falhas de mercado ${ }^{36}$ objetivando o incentivo à melhor alocação de recursos, compatibilizando suas políticas públicas e reduzindo impactos negativos. Assim, tem-se a possibilidade estatal de conduzir as

\footnotetext{
35 Nesse sentido dispões Pedro Marcos Nunes Barbosa: "Do que é relevante ao tópico sob exame, as relações jurígenas são hodiernamente contempladas pelo olhar crítico como abrangentes de centros de interesses juridicamente relevantes, que podem não estar imediatamente identificados, e que, ademais, são os nãotitulares do pólo relacional. Destarte, de uma origem teórica egoística e abstrata, o Direito caminha para um perfil humanista e pluralista, para não enxergar a relação jurídica apenas no momento patológico do vilipêndio do conjunto das faculdades jurígenas. Deste modo, a ordem jurídica evolui para enveredar uma ótica poliédrica da titularidade, perquirindo os interesses juridicamente protegíveis de terceiros partícipes do nexo relacional perante os sujeitos de direito que perfilam as aziendas comerciais virtuais. Nestas relações jurídicas, exempli gratia, ganham destaque nos outros polos do liame jurígeno o Estado, o concorrente, o fornecedor, os trabalhadores, os parceiros Mercantis e o consumidor." BARBOSA, Pedro Marcos Nunes. $O$ Estabelecimento Comercial Virtual: Universalidade, Direito à Identidade e Tutela Através de Direito Real. São Paulo, 2016. Tese de Doutorado em Direito Comercial - Faculdade de Direito Universidade de São Paulo. p.91-92

36 "Os economistas usam a expressão falha de mercado para se referirem a uma situação em que o mercado, por si só, não consegue produzir uma alocação eficiente de recursos." MANKIW, N. Gregory. Introdução à economia - Tradução: Allan Vidigal Hastings, Elisete Paes e Lima, Ez2 Translate; revisão técnica Manuel José Nunes Pinto. São Paulo: Cengage Learning, 2013. p.12
} 
externalidades ${ }^{37}$, criando incentivos de forma a orientar a alocação de recursos ou ainda atuar de forma a controlar o poder de mercado ${ }^{38}$ e atenuar seus possíveis excessos.

Desse modo, a regulação da concorrência vem atrelada a preceitos constitucionais a fim de se garantir a concretude e observância das diretrizes traçadas na Magna Carta. Assim, o direito concorrencial passa a ser visto como instrumento que viabiliza a implementação pelo Estado de suas políticas públicas. 39

\section{II.1 Sistema Brasileiro de Defesa da Concorrência}

Para valer-se desse instrumento, a atuação estatal conta com a estruturação do Sistema Brasileiro de Defesa da Concorrência - SBDC definido atualmente pela Lei $\mathrm{n}^{\circ} 12.529$ de 30 de novembro de 2011. Almejando a prevenção e repressão às infrações contra a ordem econômica o SBDC conta com o Conselho Administrativo de Defesa Econômica CADE e a Secretaria de Acompanhamento Econômico do Ministério da Fazenda - SEAE. Enquanto esta tem por competência o fomento e a promoção da concorrência no âmbito governamental e social 40 o CADE é autarquia federal com atribuição judicante ${ }^{41}$, vinculada ao Ministério da

\footnotetext{
37 Externalidade compreendida como “(...) impacto das ações de uma pessoa sobre o bem-estar dos que estão próximos. Ibid.p.12

38 Ibid. p. 12

39 "Entende-se assim, o direito antitruste como técnica de que lança mão o Estado contemporâneo para implementação de políticas publicas, mediante repressão ao abuso do poder econômico e a tutela da livre-concorrência." FORGIONI, Paula A. Op.Cit. p 84

40 Art. 19 da Lei 12.529/2011

${ }^{41}$ Contudo, deve-se fazer ressalva ao que tange a unicidade de jurisdição. Isso porque nosso ordenamento não exclui da apreciação do poder judiciário qualquer lesão ou ameaça a direito, configurando o princípio da inafastabilidade do controle jurisdicional no art. $5^{\circ} \mathrm{XXXV} \mathrm{CF}$, de modo que a atribuição judicante da autarquia não faz coisa julgada absoluta, o que implica dizer que tais decisões poderão ser revistas pelo judiciário.
} 
Justiça e composto pelo Tribunal Administrativo de Defesa Econômica, Superintendência-Geral e Departamento de Estudos Econômicos.

O Tribunal Administrativo de Defesa Econômica é órgão judicante que tem por principais atribuições: "decidir sobre a existência de infração à ordem econômica e aplicar as penalidades previstas em lei” (art. 9 $9^{\circ}$, II), "decidir os processos administrativos para imposição de sanções administrativas por infrações à ordem econômica instaurados pela Superintendência-Geral" (art. $9^{\circ}$, III), "ordenar providências que conduzam à cessação de infração à ordem econômica, dentro do prazo que determinar" (art. $\left.9^{\circ}, \mathrm{IV}\right)$, “aprovar os termos do compromisso de cessação de prática e do acordo em controle de concentrações, bem como determinar à Superintendência-Geral que fiscalize seu cumprimento" (art. $9^{\circ}, \mathrm{V}$ ) e "apreciar processos administrativos de atos de concentração econômica, na forma desta Lei, fixando, quando entender conveniente e oportuno, acordos em controle de atos de concentração" (art. $9^{\circ} \mathrm{X}$ ).

À Superintendência-Geral compete, dentre outras funções ${ }^{42}$, "promover procedimento preparatório de inquérito administrativo e inquérito administrativo para apuração de infração à ordem econômica" (art. 13, III), decidir pela insubsistência dos indícios de infração da ordem econômica e consequente arquivamento de autos do inquérito administrativo ou procedimento preparatório (art. 13, IV), "instaurar e instruir processo administrativo para imposição de sanções administrativas por infrações à ordem econômica, procedimento para apuração de ato de concentração, processo administrativo para análise de ato de concentração econômica e processo administrativo para imposição de sanções processuais incidentais instaurados para prevenção, apuração ou

\footnotetext{
${ }^{42}$ Elencadas no artigo 13 da Lei 12.529/2011
} 
repressão de infrações à ordem econômica" (art. 13, V), "sugerir ao Tribunal condições para a celebração de acordo em controle de concentrações e fiscalizar o seu cumprimento" (art. 13, X) e "adotar medidas preventivas que conduzam à cessação de prática que constitua infração da ordem econômica, fixando prazo para seu cumprimento e o valor da multa diária a ser aplicada, no caso de descumprimento" (art. 13, $\mathrm{XI})$.

E por fim, completando a tríade de constituição do CADE, o Departamento de Estudos Econômicos tem por função a elaboração de estudos e pareceres que forneçam rigor técnico e cientifico às decisões do órgão, podendo serem realizados de oficio ou a requerimento do Plenário, do Presidente, do Conselheiro-Relator ou do Superintendente-Geral (art. 17).

Além disso, o CADE conta com a assessoria especializada da Procuradoria Federal para, dentre outras incumbências ${ }^{43}$, representá-lo, prestar-lhe consultoria, promover execuções judiciais das decisões do CADE e emitir pareceres.

Posto isso, compreendendo sumariamente a mecânica estrutural do Direito Antitruste e entendo-o em uma perspectiva instrumental de implementação de políticas públicas, deve-se analisar de que modo o Direito Tributário pode estar atrelado a essa mecânica. Isto é: compreender como a tributação pode impactar a ordem econômica, em uma perspectiva concorrencial.

\footnotetext{
${ }^{43}$ Elencadas no artigo 15 da Lei $12.529 / 2011$
} 


\section{CAPÍTULO III}

\section{Poder de Tributar}

O poder de tributar reside na atribuição do Estado, decorrente da Constituição Federal, de impor tributos aos particulares como forma de auferir receita a fim de que seja viabilizada a função estatal de satisfação das necessidades públicas ${ }^{44}$, sendo, em última análise imprescindível à própria manutenção e concretização do Estado Democrático de Direito. Para Luiz Emygdio Franco da Rosa Jr:

"Assim, poder de tributar consiste no exercício do poder geral do Estado aplicado no campo da imposição de tributos. O seu fundamento reside na soberania que o Estado exerce em seu território, podendo exigir de todos os que estão a ele submetidos que contribuam, de forma obrigatória, com recursos para que possa, através do serviço publico, satisfazer as necessidades publicas. $O$ poder de tributar decorre diretamente da Constituição Federal e somente pode ser exercido pelo Estado através de lei, por delegação do povo, logo este tributa a si mesmo e a norma jurídica deve preexistir ao exercito do poder de tributar." 45

Se por um lado, o poder de tributar é expressão da soberania estatal, por outro, ele já nasce limitado pela própria Constituição ao passo que esta confere aos cidadãos garantias básicas a fim de protegê-los da voracidade estatal.

Dessa forma, impõe comedimentos à tributação como elementos mínimos que proporcionem ao povo a possibilidade de se planejar. Nesse sentido, a Magna Carta estabelece as denominadas limitações constitucionais ao poder de tributar elencadas exemplificativamente no

\footnotetext{
${ }^{44}$ Segundo Aliomar Baleeiro "Necessidade pública é toda aquela de interesse geral, satisfeita pelo processo do serviço público. É a intervenção do Estado para provê-la, segundo aquele regime jurídico, que lhe dá o colorido inconfundível. A necessidade torna-se pública por uma decisão dos órgãos políticos.” BALEEIRO, Aliomar. Uma introdução à Ciência das Finanças. 19a ed. revista e atualizada por Hugo de Brito Machado Segundo. Rio de Janeiro: Forense, 2015. p.5

${ }^{45}$ ROSA JÚNIOR, Luiz Emygdio F. da. Manual de direito tributário - 2. e. revista e atualizada Rio de Janeiro: Renovar, 2012. p. 177
} 
artigo $150^{46}$.

Dentre as limitações mais básicas encontram-se os princípios: da legalidade tributária47 48- que exige lei para a exigência ou majoração de $\operatorname{tributos}^{49}$; isonomia ${ }^{50}$ - que veda o tratamento desigual a contribuintes em situações semelhantes ou até mesmo estabelecer distinções em razão da

\begin{abstract}
${ }^{46}$ Como o próprio artigo 150 da Constituição explicita, ao utilizar a terminologia "Sem prejuízo de outras garantias asseguradas ao contribuinte (...)", a sua natureza numerus apertus de modo que as limitações ao poder de tributar encontram-se não só espalhadas pela própria constituição como em outros dispositivos legais. Nesse sentido, por exemplo: capacidade tributária: "art. $145 \S 1^{\circ}$ Sempre que possível, os impostos terão caráter pessoal e serão graduados segundo a capacidade econômica do contribuinte, facultado à administração tributária, especialmente para conferir efetividade a esses objetivos, identificar, respeitados os direitos individuais e nos termos da lei, o patrimônio, os rendimentos e as atividades econômicas do contribuinte." tipicidade tributaria, prevista no art. 97do Código Tributário Nacional: Art. 97. Somente a lei pode estabelecer:I - a instituição de tributos, ou a sua extinção;II - a majoração de tributos, ou sua redução, ressalvado o disposto nos artigos 21, 26, 39, 57 e 65;III - a definição do fato gerador da obrigação tributária principal, ressalvado o disposto no inciso I do $\S 3^{\circ}$ do artigo 52 , e do seu sujeito passivo;IV - a fixação de alíquota do tributo e da sua base de cálculo, ressalvado o disposto nos artigos 21,26 , 39,57 e $65 ; \mathrm{V}$ - a cominação de penalidades para as ações ou omissões contrárias a seus dispositivos, ou para outras infrações nela definidas;VI - as hipóteses de exclusão, suspensão e extinção de créditos tributários, ou de dispensa ou redução de penalidades.
\end{abstract}

${ }^{47}$ A legalidade tributaria encontra previsão constitucional no art. 150, I: “Art. 150. Sem prejuízo de outras garantias asseguradas ao contribuinte, é vedado à União, aos Estados, ao Distrito Federal e aos Municípios: I - exigir ou aumentar tributo sem lei que o estabeleça;". Sem prejuízo da legalidade genérica prevista no artigo 5, ${ }^{\circ}$ II :"Todos são iguais perante a lei, sem distinção de qualquer natureza, garantindo-se aos brasileiros e aos estrangeiros residentes no País a inviolabilidade do direito à vida, à liberdade, à igualdade, à segurança e à propriedade, nos termos seguintes: II - ninguém será obrigado a fazer ou deixar de fazer alguma coisa senão em virtude de lei;

48 Deve-se fazer a observação ao que tange o principio da juridicidade, isto é: revela-se imperiosa a observância não só do veiculo normativo do comando estatal, mas também a verificação da compatibilidade de tal comando com o ordenamento jurídico. Nesse sentido, dispõe Gustavo Binenjbom que: "A vinculação da Administração não se circunscreve, portanto, à lei formal, mas a esse bloco de legalidade (o ordenamento jurídico como um todo sistêmico), a que aludia Hauriou, que encontra melhor enunciação, para os dias de hoje, no que Merkl chamou de principio da juridicidade administrativa." Nota do original: "Adolf Merkl, Teoria General de Derecho Administrativo, 1935, p.132 e ss. BINENBOJM, Gustavo. Uma teoria do direito administrativo: direitos fundamentais, democracia e constitucionalização. 3a ed. revista e atualizada. Rio de Janeiro: Renovar, 2014. p. 147

49 Acrescenta-se que tal principio deve ser visto com combinação ao artigo 97 do CTN vez que consagra a tipicidade na tributação, máxima através da qual exige-se lei não apenas para a exigência ou majoração dos tributos mas também para definir todos os elementos da obrigação tributária, quais sejam: definição da hipótese de incidência, determinação do sujeito passivo, fixação da alíquota e determinação de base de calculo, bem com para previsão das hipóteses de exclusão, suspensão e extinção dos créditos tributários ou suas penalidades.

50 “Art. 150. Sem prejuízo de outras garantias asseguradas ao contribuinte, é vedado à União, aos Estados, ao Distrito Federal e aos Municípios:II - instituir tratamento desigual entre contribuintes que se encontrem em situação equivalente, proibida qualquer distinção em razão de ocupação profissional ou função por eles exercida, independentemente da denominação jurídica dos rendimentos, títulos ou direitos;" 
profissão; irretroatividade 51 - vedando a cobrança de tributos sobre fatos geradores ocorridos antes da entrada em vigor da nova lei ${ }^{52}$; anterioridade clássica53 e subsidiariamente a nonagesimal - de modo que os tributos não podem, em regra, serem cobrados no mesmo exercício financeiro ${ }^{54}$ e secundariamente, antes de ultrapassados noventas entre a publicação e a instituição ou majoração; vedação ao confisco ${ }^{55}$, capacidade contributiva ${ }^{56}$.

\footnotetext{
51 “Art. 150. Sem prejuízo de outras garantias asseguradas ao contribuinte, é vedado à União, aos Estados, ao Distrito Federal e aos Municípios:III - cobrar tributos:a) em relação a fatos geradores ocorridos antes do início da vigência da lei que os houver instituído ou aumentado;"
}

52 Lembrando que a retroatividade tributaria é admitida nas hipóteses previstas expressamente no artigo 106 do CTN, quais sejam: "Art. 106. A lei aplica-se a ato ou fato pretérito:I - em qualquer caso, quando seja expressamente interpretativa, excluída a aplicação de penalidade à infração dos dispositivos interpretados;II - tratando-se de ato não definitivamente julgado:a) quando deixe de defini-lo como infração;b) quando deixe de tratá-lo como contrário a qualquer exigência de ação ou omissão, desde que não tenha sido fraudulento e não tenha implicado em falta de pagamento de tributo; c) quando lhe comine penalidade menos severa que a prevista na lei vigente ao tempo da sua prática."

Sobre o tema destaca-se existência de embate doutrinário no que tange as alíneas a e b e a existência ou não de reprodução ou contradição entre elas. Para Luciano Amaro resta presente uma contradição vez que a alínea $b$ apesar de em sua primeira parte reproduzir a aliena a, exige posteriormente a ausência de fraude e inadimplemento tributário. Concluindo pela prevalência da alina a fundamentando-se pelo art. 112 do CTN e o princípio in dúbio pro reo. O autor ainda destaca outras posições doutrinarias:

"A contradição entre as duas alienas não escapou a Fábio Fanucchi, que anotou tratar a primeira de uma retroatividade incondicional, e a segunda de uma aplicação condicional da lei nova mais benigna. Ao propor uma solução, regulando a de Eros Grau (para quem a alínea a seria atinente a obrigações principais e a b, a obrigações acessórias), Fábio Fanucchi aventa a aplicação do princípio in duvido pro reo (que faria a letra a prevalecer sobre a b). mas conclui pela fusão dos dois preceitos (o que, na pratica, significou prestigiar a letra b). Hugo de Brito Machado também anotou que não via nenhuma diferença entre as alíneas em cotejo." AMARO, Luciano. Direito tributário brasileiro. 21. ed. - São Paulo: Saraiva, 2016. p.231-232.

53 Art. 150. Sem prejuízo de outras garantias asseguradas ao contribuinte, é vedado à União, aos Estados, ao Distrito Federal e aos Municípios:III - cobrar tributos: b) no mesmo exercício financeiro em que haja sido publicada a lei que os instituiu ou aumentou; c) antes de decorridos noventa dias da data em que haja sido publicada a lei que os instituiu ou aumentou, observado o disposto na alínea $b$;

54 Definido pela Lei 4.320 de 17 de marco de 1964 em seu artigo 34, segundo o qual : “O exercício financeiro coincidirá com o ano civil."

55 Art. 150. Sem prejuízo de outras garantias asseguradas ao contribuinte, é vedado à União, aos Estados, ao Distrito Federal e aos Municípios: IV - utilizar tributo com efeito de confisco;

56 Prevista no artigo $145 \S 1^{\circ}$ da CF, o STF já decidiu que não se aplica apenas e tão somente aos impostos, tal como literalmente redigido, mas sim a todas as espécies tributárias, devendo a correta leitura substituir o termo impostos por tributos. Nesse sentido: "IPVA. Progressividade. Todos os tributos submetem-se ao princípio da capacidade contributiva (precedentes), ao menos em relação a um de seus três aspectos (objetivo, subjetivo e proporcional), independentemente de classificação extraída de critérios puramente econômicos.[RE 406.955 AgR, rel. min. Joaquim Barbosa, j. 4-10-2011, 2a T, DJE de 21-10-2011.]" 
Ocorre que as ditas limitações não são absolutas, comportando exceções previstas na própria constituição. Dentre as justificativas para essas excepcionalidades encontra-se a classificação tributária quanto a finalidade, isto é, há tributos os quais o objetivo precípuo não é a mera arrecadação (fim fiscal), mas sim representam uma função instrumental de intervenção nos domínios econômico e social (fim extrafiscal), como por exemplo o imposto sobre importação (art. 153, I CF), imposto sobre exportação (art. 153, II CF), imposto sobre operações de credito, cambio, seguro e títulos ou valores mobiliários - IOF (art. 153, V CF), imposto predial territorial urbano progressivo no tempo (art. 182, $\S 4^{\circ} \mathrm{CF}$ ), e imposto territorial rural - ITR (art. 153, $\left.\S 4^{\circ}, \mathrm{I} C F\right)$.

Desse modo, admite-se aos tributos uma função que ultrapassa a mera obtenção de recursos ao estado, configurando assim, modo de indução do mercado. Reconhece-se sua repercussão na economia de tal modo que a tributação afeta o comportamento dos agentes, e serve ao Estado como mecanismo de intervenção na ordem econômica.

Inclusive, pode-se dizer que o próprio Supremo Tribunal Federal, por ocasião do julgamento do Recurso Extraordinário 253.472 SP, de relatoria do Ministro Marco Aurélio, reconheceu a necessidade de avaliação de efeitos colaterais provocados pela aplicabilidade da imunidade tributária. $\mathrm{O}$ caso envolveu a análise se as instalações portuárias de propriedade da União, mas sob a responsabilidade da Companhia Docas do Estado de São Paulo fariam jus à imunidade tributaria recíproca e assim teriam afastada a incidência do IPTU sobre as ditas instalações. A corte além de tecer considerações sobre o sujeito passivo do IPTU concluiu que se tratava de serviço publico, que o controle acionário era quase em sua totalidade da União e que não havia riscos de quebra do equilíbrio concorrencial ou da 
livre iniciativa, explicitou que a proteção constitucional decorrente da imunidade recíproca depende da análise de três estágios, dentre eles que:

"A desoneração não deve ter como efeito colateral a quebra dos princípios da livre-concorrência e do exercício de atividade profissional ou econômica licita. Em principio, o sucesso ou a desventura empresarial devem pautar-se por virtudes e vícios próprios do mercado e da administração, sem que a intervenção do Estado seja favor preponderante." 57

Dessa forma, vislumbra-se possível o afastamento pontual de uma imunidade em decorrência de infrações à livre inciativa ou à livre concorrência..$^{58}$ caracterizando-se, desde já, a potencialidade da repercussão da tributação na esfera econômica e o afastamento de uma eventual neutralidade tributária.

57 Também no Recurso Extraordinário 599.176 PR o Min. Joaquim Barbosa se manifestou no sentido que: "Segundo a jurisprudência desta Suprema Corte, a imunidade tributária recíproca é um instrumento de calibração do pacto federativo, destinado a proteger os entes federados de pressões econômicas projetadas para induzir escolhas políticas ou administrativas da preferência do ente tributante (remeto, exemplificativamente, ao RE 253.472, red. p/ acórdão min. Joaquim Barbosa, Pleno, DJe de 10.02.2011). Nesse contexto, a imunidade tributária recíproca é inaplicável se a atividade ou a entidade tributada demonstrarem capacidade contributiva, se houver risco à livre-iniciativa e às condições de justa concorrência econômica ou se não estiver em jogo risco ao pleno exercício da autonomia política conferida aos entes federados pela Constituição." (grifo nosso)

58 Por ocasião do julgamento do Agravo Regimental no Agravo de Instrumento 558682 SP de relatoria do Min. Joaquim Barbosa em trecho da ementa fica claro tal possibilidade: "O foco na obtenção de lucro, a transferência do benefício a particular ilegítimo ou a lesão à livre iniciativa e às regras de concorrência podem, em tese, justificar o afastamento da imunidade". 


\section{CAPÍTULO IV}

\section{Utopia da Neutralidade Tributária}

A neutralidade tributária, entendida como ausência de impacto da tributação no mercado ${ }^{59}$, incluída de forma mais clara na Constituição Federal de 1988 com o artigo 146-A através da Emenda Constitucional no 42 de $2003{ }^{60}$ demonstra-se por demasiado idealista. Antes de tal emenda, o dito princípio era identificado como decorrência do artigo 150, II61 da Constituição, atrelado portanto ao princípio da isonomia. ${ }^{62}$

Ocorre que entender a neutralidade em termos absolutos nos leva a negativa do próprio sistema constitucional que, como se viu, permite a utilização dos tributos com fins extrafiscais e até mesmo como método de

\footnotetext{
59 Para Rodrigo Maito da Silveira: "A essência do principio da neutralidade tributaria repousa na ideia de que a tributação não deve afetar o comportamento dos agentes econômicos." SILVEIRA, Rodrigo Maito da. Tributação e Concorrência - Série Doutrina Tributaria Vol. IV São Paulo: Quartier Latin, 2011. p. 38
}

60 “Art. 146-A. Lei complementar poderá estabelecer critérios especiais de tributação, com o objetivo de prevenir desequilíbrios da concorrência, sem prejuízo da competência de a União, por lei, estabelecer normas de igual objetivo."

61 “Art. 150. Sem prejuízo de outras garantias asseguradas ao contribuinte, é vedado à União, aos Estados, ao Distrito Federal e aos Municípios:II - instituir tratamento desigual entre contribuintes que se encontrem em situação equivalente, proibida qualquer distinção em razão de ocupação profissional ou função por eles exercida, independentemente da denominação jurídica dos rendimentos, títulos ou direitos;"

62 Sobre a diferença entre os artigos 150, II e 146-A, dispõe Vinicius Alberto Rossi Nogueira : "Embora se possa extrair uma preocupação semelhante com os princípios da capacidade contributiva e isonomia tributária por parte do artigo 146-A, esta preocupação se dá de maneira mediata, uma vez o objetivo primordial da norma é evitar distúrbios concorrenciais nos mercados. Ou seja, é por meio da prevenção dos distúrbios concorrenciais que se alcança a igualdade e a capacidade contributiva. Ademais, o artigo 146-A permite ao legislador complementar alcançar situações que dificilmente seriam alcançadas pelo artigo 150, II. Isto porque o artigo 150, II, tal como o artigo 146, II, mencionado acima, é dirigido à relação Fisco x contribuinte, no âmbito das limitações ao poder de tributar (seção II), mitigando competência específica de um ente tributante, em sua singularidade. Ele busca, portanto, limitar o poder de um ente tributante em função dos direitos individuais de seus contribuintes. O artigo 146-A, por sua vez, dirige-se ao conflito de competências, ou seja, ele busca harmonizar os diversos exercícios de competência dentro da federação a fim de prevenir distorções concorrenciais." NOGUEIRA, Vinicius Alberto Rossi. Direito tributário e livre concorrência: da interpretação e aplicação do artigo 146-A da Constituição Federal. São Paulo, 2014. Dissertação de Mestrado . Faculdade de Direito da Universidade de São Paulo. p. 85 


\title{
correção e prevenção de desequilíbrios concorrenciais - e assim,
}

\section{caracterizando-os com uma finalidade indutiva. ${ }^{63}$}

\author{
Sendo assim, dispõe Rodrigo Maito da Silveira que:
}

“Como decorrência lógica do pressuposto de que os tributos afetam a alocação de recursos na economia, a neutralidade (enquanto fenômeno econômico) revela-se utópica ${ }^{64}$, pois não pode supor que a tributação, por mais fiel que seja ao princípio da isonomia e da capacidade contributiva, produza os mesmos efeitos em relação a contribuintes em situação de igualdade. A igualdade é sempre relativa. Em maior ou menor grau, sempre haverá influencia do tributo sobre o comportamento dos contribuintes. ${ }^{65}$ Do mesmo modo, a neutralidade também é relativa. ${ }^{66 "} 67$ (grifos nossos)

(...)

"Sob outra perspectiva, é mais razoável supor que o princípio da neutralidade tributaria destina-se a evitar que a tributação, enquanto modalidade de intervenção econômica do Estado, cause desequilíbrios concorrenciais. É o que enfatiza SCHOUERI, ao concluir que seria mais adequado "admitir que a neutralidade tributária não significa a não interferência do tributo sobre a economia, mas, em acepção mais restrita, neutralidade da tributação em relação à livre concorrencia, visando a garantir um ambiente de igualdade de condições competitivas, reflexo da neutralidade concorrencial do Estado "68. "69

Assim, reconhece-se à tributação um teor indutivo ao passo que repercute no mercado. De outro lado, é possível identificá-lo como

63 José Ribeiro Brazuna chama a atenção para tanto: "De fato, se partirmos da ideia de neutralidade como absoluta ausência de interferência da tributação sobre o livre funcionamento dos mercados, será impossível falar em neutralidade tributária no caso da Constituição Federal de 1988, que é pródiga em permissões para a tributação extrafiscal e indutora." BRAZUNA, José Luis Ribeiro. Defesa da Concorrência e Tributação - à luz do Artigo 146-A da Constituição - Série Doutrina Tributária Vol. II - São Paulo: Quartier Latin, 2009. p. 142

64 SILVEIRA, Rodrigo Maito da. Op. Cit. p.39. Nota $\mathrm{n}^{\circ} 50$ do Original: "Concordando com tal proposição ao afirmar que a neutralidade da tributação seria um mito, vide: SCHOUERI, Luís Eduardo. Tributação e Indução Econômica: os Efeitos Econômicos de um Tributo como Critério para sua Constitucionalidade. In: Princípios e Limites da Tributação 2. Coord. Roberto Ferraz. São Paulo: Quartier Latin, 2009. p.140-164 (p.142)

65 Ibid. Nota do Original no 51 SCHOUERI, Luís Eduardo. Livre Concorrência e Tributação. In: Grandes Questões Atuais do Direito Tributário. Vol. 11. Coord. Valdir de Oliveira Rocha. São Paulo: Dialética, 2007. p. 253

66. Ibid. Nota do Original $\mathrm{n}^{\circ} 52$ Cf. SANTOS, António Carlos dos. Auxílios de Estado e Fiscalidade. Coimbra: Almedina, 2003. p. 355

67 Ibid. p 39

68 Ibid. Nota do Original n55 SCHOUERI, Luís Eduardo. Livre Concorrência e Tributação. In: Grandes Questões Atuais do Direito Tributário. Vol. 11. Coord. Valdir de Oliveira Rocha. São Paulo: Dialética, 2007. p.254.

${ }^{69}$ Ibid. p.40. 
instrumento de que se pode valer o Estado para atuar na prevenção de desequilíbrios concorrenciais. Dessa forma, a neutralidade tributária afastase da idéia utópica de absoluta não intervenção estatal na ordem econômica por meio da tributação para ser entendida, em termos relativos, como parâmetro da ausência de efeitos nocivos à concorrência. ${ }^{70}$

Contudo, essa afirmação merece breves esclarecimentos. Ao que pese a função instrumental da tributação ressaltada pelo artigo 146-A da Constituição tal instrumentalidade derivada desse artigo não implica à possibilidade de utilização dos tributos como meio de corrigir falhas concorrenciais estruturais, mas sim apenas aquelas decorrentes do próprio poder de tributar, sob pena de distorção ou sobreposição de funções ao que tange o papel do Sistema Brasileiro de Defesa da Concorrência. Nessa linha, defende Rodrigo Maito da Silveira que:

"Insista-se: à luz do artigo 146-A, a tributação não pode, mesmo que a lei complementar (ou ordinária, no caso da União Federal) estabeleça os critérios para tanto, ser utilizada como instrumento de repressão de abusos. Esta é uma função do Sistema Brasileiro de Defesa da Concorrência. A tributação como forma de correção ( a posteriori) de falhas estruturais já existentes, por sua vez, será legitima no campo da extrafiscalidade."71

Isso significa que o artigo 146-A não autoriza a edição dos critérios especiais de tributação com a finalidade de corrigir falhas estruturais do sistema concorrencial72, mas sim, para prevenir que haja desequilíbrio concorrencial derivado da tributação.

Desse modo, para que se tenha a atuação estatal tributária no sentido de intervenção econômica deve-se valer dos tributos extrafiscais e não da

\footnotetext{
70 "Quando se entende a neutralidade tributária sob o enfoque da ausência de efeitos contrários à livre concorrência, percebe-se que se trata de princípio coerente com a realidade de indução e extrafiscalidade impregnada no texto constitucional” BRAZUNA, José Luis Ribeiro. Op. Cit. p143

${ }^{71}$ Ibid. p108.

72 "O artigo 146-A apenas contempla a possibilidade de o legislador, preventivamente, a partir $\mathrm{dr}$ critérios estipulados em lei complementar, minimizar ou mitigar os efeitos negativos que um determinado tributo possa gerar na concorrência entre os contribuintes. Nada além disso." Ibid. p. 108
} 
edição de lei complementar para estabelecer critérios especiais de tributação, tanto porque o próprio artigo 146-A refere-se a prevenção e não repressão como pelo fato de gozar o sistema concorrencial de estrutura própria para correção de falhas. Em suma, o artigo 146-A limita-se a correção dos efeitos anticoncorrenciais produzidos pela própria tributação, sendo inviável uma interpretação mais ampla. ${ }^{73}$

Assim, superada a questão da suposta neutralidade tributária e compreendendo a instrumentalização do Direito Tributário na ordem econômica faz-se necessária a análise dos impactos derivados de tal atuação na tomada de decisão dos agentes do mercado.

73 “O que se quer dizer é que o artigo 146-A, embora sua redação não deixe isso claro, somente se aplica em relação a desequilíbrios concorrenciais oriundos da própria tributação. Entendê-lo com um escopo mais abrangente, para permitir a repressão de praticas econômicas lesivas à concorrência que decorram (ou não) de fatores tributários, é permitir que todos os entes políticos utilizem normas tributarias para preservar o equilíbrio do mercado, de forma completamente assistemática e descentralizada." Ibid. p105 


\section{CAPÍTULO V}

\section{Custos da Tributação ao Mercado}

Fato é que os agentes do mercado antes da tomada de decisão sobre determinado negócio ou operação se preocupam com seus custos, tentando projetá-los através de um planejamento geral. Aqui o planejamento tributário aparece com instrumento que viabiliza tal previsibilidade, fornecendo caminhos menos tortuosos, mais econômicos e eficientes ao setor privado.

Ocorre que desde logo deve-se fazer uma ponderação no que tange o liame de licitude na conduta do planejamento. Isto é, deve-se distinguir as praticas elisivas das evasivas.

Em suma, apesar do dissenso doutrinário na definição de tais institutos, tem-se basicamente que a elisão constitui a conduta prévia a ocorrência do fato gerador com o objetivo de suprimir ou reduzir a incidência da carga tributária, através de mecanismos lícitos. Enquanto isso, a evasão é o emprego de vias ilícitas na fuga da tributação no momento ou após a ocorrência do fato gerador, tais como a simulação, a fraude e a sonegação.

Desse modo, valendo-se dos critérios cronológico e instrumental tem-se que a elisão é preparação do eventual contribuinte para evitar a concretização da hipótese de incidência ${ }^{74}$ através de conduta compatível com o ordenamento jurídico. Por outro lado, a evasão fiscal enquadra-se na conduta concomitante ou posterior à ocorrência do fato gerador de modo

\footnotetext{
${ }^{74}$ Segundo Geraldo Ataliba: "A h.i., é primeiramente a descrição legal de um fato; é a formulação hipotética, prévia e genérica, contida na lei, de um fato (é o espelho do fato, a imagem conceituar de um fato; é seu desenho). É, portanto, mero conceito, necessariamente abstrato. É formulado pelo legislador fazendo abstração de qualquer fato concreto. Por isso é mera "previsão legal" (a lei é, por definição, abstrata, impessoal e geral). ATALIBA, Geraldo. Hipótese de Incidência Tributária. $5^{\text {a }}$ ed. $8^{a}$ tiragem..São Paulo: Malheiros, 1992. p.53
} 


\title{
que visa evadir o pagamento da carga tributaria devida ${ }^{75}$. Em suma, nas
}

\author{
palavras de Sacha Calmon:
}

"Tanto na evasão comissiva ilícita como na elisão fiscal existe uma ação do contribuinte, intencional, com o objetivo de não pagar ou pagar tributo a menor. As diferencia: (a) a nature- za dos meios empregados. Na evasão ilícita os meios são sempre ilícitos (haverá fraude ou simulação de fato, documento ou ato jurídico. Quando mais de um agente participar dar-se-á o conluio). Na elisão os meios são sempre lícitos porque não ve- dados pelo legislador; (b) também, o momento da utilização desses meios. Na evasão ilícita a distorção da realidade ocorre no momento em que ocorre o fato jurígeno-tributário (fato gera- dor) ou após sua ocorrência. Na elisão, a utilização dos meios ocorre antes da realização do fato jurígeno-tributário, ou como aventa Sampaio Dória, antes que se exteriorize a hipótese de incidência tributária, pois, opcionalmente, o negócio revestirá a forma jurídica alternativa não descrita na lei como pressuposto de incidência ou pelo menos revestirá a forma menos onerosa." 76

Nesse sentido, dentre outras medidas, aparece a figura do

planejamento tributário como instrumento mediante o qual o contribuinte

75 “INCORPORAÇ̃̃O. AUTUAÇ̃̃O. ELISÃO E EVASÃO FISCAL. LIMITES. SIMULAÇÃO.EXIGIBILIDADE DO DÉBITO. 1. Dá-se a elisão fiscal quando, por meios lícitos e diretos o contribuinte planeja evitar ou minimizar a tributação. Esse planejamento se fundamenta na liberdade que possui de gerir suas atividades e seus negócios em busca da menor onerosidade tributária possível, dentro da zona de licitude que o ordenamento jurídico lhe assegura. 2. Tal liberdade é possível apenas anteriormente à ocorrência do fato gerador, pois, uma vez ocorrido este, surge a obrigação tributária. 3. A elisão tributária, todavia, não se confunde com a evasão fiscal, na qual o contribuinte utiliza meios ilícitos para reduzir a carga tributária após a ocorrência do fato gerador. 4. Admite-se a elisão fiscal quando não houver simulação do contribuinte. Contudo, quando o contribuinte lança mão de meios indiretos para tanto, há simulação. $\mathbf{5}$. Economicamente inviável a operação de incorporação procedida (da superavitária pela deficitária), é legal a autuação. 6. Tanto em razão social, como em estabelecimento, em funcionários e em conselho de administração, a situação final - após a incorporação - manteve as condições e a organização anterior da incorporada, restando demonstrado claramente que, de fato, esta "absorveu" a deficitária, e não o contrário, tendo-se formalizado o inverso apenas a fim de serem aproveitados os prejuízos fiscais da empresa deficitária, que não poderiam ter sido considerados caso tivesse sido ela a incorporada, e não a incorporadora, restando evidenciada, portanto, a simulação. 7. Não há fraude no caso: a incorporação não se deu mediante fraude ao fisco, já que na operação não se pretendeu enganar, ocultar, iludir, dificultando - ou mesmo tornando impossível a atuação fiscal, já que houve ampla publicidade dos atos, inclusive com registro nos órgãos competentes. 8. Inviável economicamente a operação de incorporação procedida, tendo em vista que a aludida incorporadora existia apenas juridicamente, mas não mais economicamente, tendo servido apenas de "fachada" para a operação, a fim de serem aproveitados seus prejuízos fiscais cujo aproveitamento a lei expressamente vedava. 9. Uma vez reconhecida a simulação deve o juiz fazer prevalecer as consequêencias do ato simulado - no caso, a incorporação da superavitária pela deficitária, conseqüentemente incidindo o tributo na forma do regulamento - não havendo falar em inexigibilidade do crédito, razão pela qual a manutenção da decisão que denegou a antecipação de tutela pretendida se impõe." (Tribunal Regional Federal -4a Região - AG: 44424 RS 2004.04.01.044424-0, Relator: DIRCEU DE ALMEIDA SOARES, Porto Alegre,Data de Julgamento: 30/11/2004, SEGUNDA TURMA, Data de Publicação: DJ 26/01/2005 PÁGINA: 430)

${ }^{76}$ COÊLHO, Sacha Calmon Navarro. Teoria da Evasão e da Elisão em Matéria Tributária. Disponível em: http://49ga9f10blgreaqid23bdv7s-wpengine.netdna-ssl.com/wp-content/uploads/ 2010/12/Evasão-e-Elisão-Dialética.pdf> Acesso em: 20 out. 2017. p.9 
traça estratégias lícitas objetivando percorrer caminhos tributariamente menos onerosos, isto é, vale-se da própria lei e, não à sua margem, para despender menos recursos com tributos. Como destaca Aliomar Baleeiro: "A elisão deve ser tratada como instrumento inerente ao modo capitalista de produção, competitivo e concentracionista, e configura mesmo um dever, do ponto de vista da empresa". ${ }^{77}$ Inclusive aponta-se o planejamento tributário como atrelado ao dever de diligência dos administradores de sociedades anônimas ${ }^{78}$, desse modo André Mendes Moreira dispõe que:

"A estruturação dos negócios jurídicos de modo a arcar-se com o menor ônus tributário possível, utilizando-se de formas legais (não veda- das pelo ordenamento jurídico) é prática corriqueira das empresas e, menos comumente, de pessoas naturais. O planejamento tributário é inclusive dever dos administradores de sociedades anônimas, conforme se infere do dispos- to na Lei no 6.404, de 15 de dezembro de 1976, in verbis:

"Art. 153. O administrador da companhia deve empregar, no exercício de suas funções, o cuidado e diligência que todo homem ativo e probo costuma empregar na administração dos seus próprios negócios.

Art. 154. O administrador deve exercer as atribuições que a lei e o estatuto the conferem para lograr os fins e no interesse da companhia, satisfeitas as exigências do bem público e da função social da empresa."

Assim, a prévia estruturação das atividades empresariais com o fito de pagar menos tributos - planejamento tributário - é não somente di- reito de todos como dever inarredável daqueles a quem foi confiada a admi- nistração de sociedades anônimas, que devem gerir a poupança popular tão bem como o fazem com seu próprio patrimônio. Isso implica em, sempre que possível, permitir que a Fazenda Pública se apodere da quantia mínima do capital social empregado nos negócios da companhia."79

Ainda sobre o tema, necessário tecer considerações sobre a possibilidade de desconsideração, pela autoridade administrativa, dos atos ou negócios praticados com intuito de dissimulação, através da Lei

\footnotetext{
77BALEEIRO, Aliomar.. Op. Cit. p. 1105

78 Art. 153. O administrador da companhia deve empregar, no exercício de suas funções, o cuidado e diligência que todo homem ativo e probo costuma empregar na administração dos seus próprios negócios.

79 MOREIRA, André Mendes. ELISÃO E EVASÃO FISCAL - LIMITES AO PLANEJAMENTO TRIBUTÁRIO. disponível em $<$ http://sachacalmon.wpengine.netdna-cdn.com/wp-content/uploads/ 2010/10/O-Planejamento-Tributario-sob-a-otica-do-Codigo-Tributario-Nacional.pdf $>$ Acesso em: out $/ 2017$. p. 7
} 
Complementar $\mathrm{n}^{\circ} 104$ de 2001 que incluiu o parágrafo único ao artigo 116 com a seguinte redação:

“Art. 116. Parágrafo único. A autoridade administrativa poderá desconsiderar atos ou negócios jurídicos praticados com a finalidade de dissimular a ocorrência do fato gerador do tributo ou a natureza dos elementos constitutivos da obrigação tributária, observados os procedimentos a serem estabelecidos em lei ordinária."

Tal preceito legislativo não pode ser apontado como norma antielisiva, visto que, como exposto, a elisão fiscal pressupõe a utilização de meios lícitos, em conformidade com o direito pátrio. De tal sorte, estão sob a abrangência da referida disposição as condutas atreladas à praticas evasivas, já que a dissimulação é fato ilícito. Desse modo tem-se que:

“O Código Tributário Nacional, no art. 116, não está coibindo a elisão ou o planejamento tributário, por si lícito, mas sim a simulação, sempre ilícita. Na elisão os meios são lícitos e o ato ou negócio jurídico é real, desencadeia efeitos próprios, não mascara a ocorrência do fato gerador e há compatibilidade entre forma e conteúdo. Na elisão, o fato, ato ou negócio jurídico pressuposto na norma simplesmente não acontece." 80

Sendo assim, apesar da motivação legislativa externalizada no item $6^{81}$ da Exposição de Motivos do Projeto de Lei Complementar no 77/1999 que foi transformado na Lei Complementar 104/2001 - apontar para um intuito anti-elisivo, percebe-se a impossibilidade de sua ocorrência, devendo-se entender a natureza da jurídica do dispositivo em questão como verdadeira regra anti-evasiva. ${ }^{82}$

Ademais, deve-se tratar ainda da interpretação econômica do direito tributário. Tal interpretação remonta ao Código Tributário Alemão de 1919

\footnotetext{
80 BALEEIRO, Aliomar. Op. Cit. p. 1106

81 “A inclusão do parágrafo único ao art. 116 faz-se necessária para estabelecer, no âmbito da legislação brasileira, norma que permita à autoridade tributária desconsiderar atos ou negócios jurídicos praticados com a finalidade de elisão, constituindo-se, dessa forma, em instrumento eficaz para o combate aos procedimentos de planejamento tributário praticados com abuso de forma ou de direito."

82 “Ora, o art. 116 refere-se à dissimulação fraudulenta, aquela ilícita, que oculta a ocorrência do fato gerador ou da natureza dos elementos constitutivos da obrigação. Portanto, visa a coibir a simulação que viola disposição de lei tributaria e, que, portanto, não pode ter validade jurídica." BALEEIRO, Aliomar. Op. Cit. p. 1106
} 
(Reichsabgabenordung-RAO), influenciado por Enno Becker, que dispunha em seu artigo $6^{\circ}$ :

"1.Através do abuso de forma ou da aparência do direito civil não pode a obrigação tributaria ser contornada ou diminuída.

2. Havendo abuso de forma, o imposto será exigido como se tivessem sido adotados os processo econômicos, os fatos geradores e as relações adequadas à forma jurídica." 83

Através dela, é possível a desconsideração de ato ou negocio jurídico em razão de uma análise eminentemente econômica das formas jurídicas, permitindo-se assim um reequadramento formal com base na realidade econômica. Segundo Aliomar Baleeiro:

"A chamada interpretação segundo o critério econômico consiste em apreender o sentido das normas, institutos e conceitos jurídicos, de acordo com a realidade econômica subjacente por detrás das formas jurídicas." 84

Ocorre que a dita interpretação econômica, revogada na própria Alemanha pelo Código Tributário de 197785 , através de seu artigo 42, não encontra respaldo no ordenamento pátrio, seja pela imposição constitucional de observância ao princípio da legalidade (art. 5º , II e art. 150, I da $\mathrm{CF} / 88$ ) seja pela disposição do próprio Código Tributário Nacional em seu artigo 110 que traz a supremacia do Direito Privado no que tange "a definição, o conteúdo e o alcance de institutos, conceitos e formas de direito privado, utilizados, expressa ou implicitamente, pela Constituição Federal, pelas Constituições dos Estados, ou pelas Leis Orgânicas do Distrito Federal ou dos Municípios, para definir ou limitar

83TORRES, Ricardo Lobo Planejamento tributário: elisão abusiva e evasão fiscal. $2^{\circ}$.ed. Rio de Janeiro: Elsevier, 2013.p. 28

\footnotetext{
${ }^{84}$ BALEEIRO, Aliomar. Op. Cit. p. 1108

85 Revogada em sua acepção original, e atualmente invocada em raras ocasiões nos tribunais germânicos como atrelados à capacidade contributiva, isto é: “ Assim, a interpretação econômica, que serviu a um regime totalitário, foi erradicada da apropria Alemanha, onde prosperou em tempos sombrios. Hoje, o critério "econômico", que se invoca eventualmente na interpretação por um tribunal tedesco, serve à apuração da capacidade economia de contribuir e somente se justifica, na medida em que, dentro dos limites dos sentidos possíveis da palavra, colher aquele sentido que melhor se ajustar aos postulados da justiça tributária.” Ibid. p. 1071
} 
competências tributárias" (art. $10 \mathrm{CTN}$ ) que não poderão ser dispostas de modo diverso pela legislação tributária. ${ }^{86}$

Entende-se ser o planejamento tributário uma liberdade de escolha do contribuinte e nesse sentido inexigível para tanto qualquer justificativa, vez que dentro dos limites legais estabelecidos pelo próprio Estado, está o contribuinte elegendo o caminho que lhe parece menos oneroso fiscalmente. ${ }^{87}$ Dispor o contrário significaria compelir o contribuinte à pratica do fato gerador do tributo mais dispendioso. ${ }^{88} 89$ Por outro lado, tal

\footnotetext{
86 Dispõe André Mendes Moreira que: "Efetuando-se uma interpretação sistemática da Constituição Federal e do Código Tributário Nacional, restam claras as razões pelas quais a interpretação econômica não encontra guarida no direito tributário pátrio. O princípio da legalidade, de cunho constitucional, é previsto no art. 5o, II da Carta Magna de forma genérica e, especificamente no que tange à lei tributária, no inciso I do art. 150 do mesmo diploma. Este se desdobra em três outros princípios: o da reserva absoluta de lei formal, o da estrita legalidade e o da especificidade conceitual fechada. Assim, somente lei em sentido formal e material pode instituir ou majorar tributos." MOREIRA, André Mendes. Op. Cit. p. 13-14

87 Nesse sentido, Luciano Amaro dispõe: "Uma afirmação inicial não polemica é a de que o indivíduo não é obrigado, entre dois caminhos lícitos, a optar por aquele que tenha maior incidência de tributos, o que, em rigorosa simetria, significa que ele pode escolher, entre dois caminhos lícitos, aquele que seja fiscalmente menos oneroso. Parece-nos que há um desdobramento necessário dessa assertiva. Se o indivíduo tem a liberdade de optar pelo caminho fiscalmente menos oneroso, isso implica que ele não precisa justificar sua opção com nenhuma outra razão que não a sua liberdade de escolha." (grifos do original) AMARO, Luciano. Op. Cit. p.257
}

88 Luciano Amaro: "Em suma, não vemos ilicitude na escolha de um caminho fiscalmente menos oneroso, ainda que a menor onerosidade seja a única razão da escolha desse caminho. Se assim não fosse, ter-se-ia de concluir, por implicação lógica, pelo absurdo de que o contribuinte seria sempre obrigado a escolher o caminho de maior onerosidade fiscal." (grifos do original.) Ibid. p. 263

${ }^{89}$ Merece ressalva a discussão doutrinária no que tange a possibilidade de desconsideração de atos ou negócios jurídicos praticados com o intuito de dissimular a ocorrência do fato gerador ou da natureza dos elementos da obrigação tributária, acrescida através da Lei Complementar $\mathrm{n}^{\circ} 104$ de 10 de janeiro de 2011 que incluiu no artigo 116 do Código Tributário Nacional seu parágrafo único. Para tanto, remete-se à pesquisa efetuada na Dissertação de Mestrado "Planejamento tributário na jurisprudência do Conselho Administrativo de Recursos Fiscais: desafios de uma pesquisa empírica" disponível em: <http://bibliotecadigital.fgv.br/dspace/handle/10438/8377> acesso: outubro/2017. Na qual Valter Pedrosa Barreto Júnior analisa de que forma o CARF justifica as autuações e quais elementos tendem a direcionar o julgamento do processo administrativo. Ainda sobre o tema: "Os limites e o futuro do planejamento tributário no Brasil em face da atuação das autoridades fiscais e da jurisprudência dos tribunais administrativos" de autoria de VAZ, Paulo Cesar Ruzisca e MIGUITA, Diego Aubin. Os limites e o futuro do planejamento tributário no Brasil em face da atuação das autoridades fiscais e da jurisprudência dos tribunais administrativos. In: Direito tributário contemporâneo: estudos em homenagem a Luciano Amaro / MARTINS, Ives Granda da Silva. e PASIN, João Bosco Coelho (Coordenadores) - São Paulo: Saraiva, 2013. 
liberdade deve observar limites, isto é, não pode ser exercida de modo absoluto. Rodrigo Maito da Silveira chama atenção à potencialidade danosa do planejamento tributário:

"Nesse sentido, a pratica concorrencial danosa também poderá ser verificada quando o planejamento tributário de uma empresa, para alem da economia de tributos, preste-se à dominação de mercados, à eliminação de concorrência ao aumento arbitrário de lucros ou ao exercício abusivo de posição dominante." 90

Além disso, em perspectivas globais e tendo por parâmetro aspectos de planeamento tributário internacional pode-se mencionar ainda como fator de planejamento tributário não só o fluxo migratório de sociedades empresárias para paraísos fiscais - ou países com tributação favorecida ${ }^{91}$ como também da pratica conhecida como treaty shopping. Definida por Ricardo Lobo Torres como:"forma de abuso das convenções internacionais contra a dupla tributação"92, e por Rodrigo Maito da Silveira como "forma de planejamento tributário internacional, implementado mediante a interposição de pessoa, justamente para buscar a aplicabilidade artificiosa de um determinado tratado contra a bitributação"93. Tal mecanismo pode ser utilizado pelas empresa como forma de infração à concorrência a medida que pode desencadear uma estruturação elaborada a fim de almejar uma “dupla não tributação". 94

No entanto, o que se deve ponderar é qual o real impacto desses custos tributários ao mercado, de modo que a tributação possa ser vista

\footnotetext{
${ }^{90}$ SILVEIRA, Rodrigo Maito da. Op. Cit. p. 304

${ }^{91}$ Assim previstos na Instrução Normativa da Receita Federal Brasileira $N^{\circ}$ 1037, de 04 de junho de 2010

92 TORRES, Ricardo Lobo. Op. Cit. p. 81

93 SILVEIRA, Rodrigo Maito da. Op. Cit..p. 305

${ }^{94}$ Segundo SILVEIRA: "Tal fenômeno ocorre quando os Estado que poderiam exercer pretensão impositiva deixam de fazê-lo, por entenderem que, à luz da situação concreta, que sua competência tributaria estaria mitigada em função da aplicação de tratado(s) contra bitributação" SILVEIRA, Ibid. p.306
} 
como peso morto na medida em que obsta ou dificulta a obtenção de ganhos. Na definição de Gregory Mankiw, peso morto se refere à “queda do excedente tal que resulta quando um imposto (ou outra política) distorce um resultado de mercado"95. Nessa esteira a implementação tributária deve levar em conta não apenas os aspectos formais de limitações ao poder de tributar tratadas no capitulo anterior, mas também a análise mercadológica no que tange às distorções ou estímulos à atuação dos players. A relevância dessa análise reside tanto no conduzir das políticas públicas a serem implementadas no setor concorrencial como na própria compreensão se os ganhos estatais com a tributação, isto é, se o aumento da receita tributaria derivada $^{96}$ é superior, e mais benéfico, que os efeitos provocados no setor privado.

Outro fator que deve ser visto é a questão dos preços predatórios, definido na Resolução no 20/99 pelo CADE como: "prática deliberada de preços abaixo do custo variável médio, visando eliminar concorrentes para, em momento posterior, poder praticar preços e lucros mais próximos do nível monopolista". A tributação, seja mediante o inadimplemento tributário, seja através das concessões de isenções, incentivos e benefícios fiscais pode contribuir para tal pratica atentatória da ordem econômica, expressamente na Lei 12.529 de 2011:

"Art. $36 \S 3$ o As seguintes condutas, além de outras, na medida em que configurem hipótese prevista no caput deste artigo e seus incisos, caracterizam infração da ordem econômica:

$\mathrm{XV}$ - vender mercadoria ou prestar serviços injustificadamente abaixo do preço de custo;"

95 MANKIW, N. Gregory. Op. Cit. p. 151

96 Segundo Ricardo Lobo Torres a classificação mais utilizada da receita publica é a que as separa em derivadas e originárias. Nesse sentido: "Derivadas são as provenientes da economia privada, representadas pelo tributo, pelos ingressos parafiscais e pelas multas. Originárias são as que decorrem da exploração do patrimônio do Estado, compreendendo os preços públicos, as compensações financeiras e os ingressos comerciais." TORRES, Ricardo Lobo. Curso de direito financeiro e tributário - $17^{\mathrm{a}}$ ed. - Rio de Janeiro: Renovar. 2010. p.186 
Isso porque, como vimos a tributação a medida que influencia na alocação dos recursos pelo agente econômico serve como artificio para pratica dos preços predatórios.

Dessa feita, tem-se que se as pessoas reagem a incentivos ${ }^{97}$ há de se saber se a reação do mercado à tributação trará ganhos maiores ao interesse público e ao bem estar social ou se acarretará uma alocação ineficiente de recursos ou quiçá medidas anticompetivivas. Sendo assim, a incidência tributaria $^{98}$ trata-se de fator que deve ser levado em consideração pelo Estado no exercício do poder de tributar, por exemplo, na concessão de benefícios e incentivos fiscais.

97 "Um incentivo é algo que induz uma pessoa a agir, tal como a perspectiva de uma punição ou recompensa. Como as pessoas racionais tomam decisões comparado custo e beneficio, elas respondem a incentivos.” MANKIW, N. Gregory. Op. Cit. p.7

98 Segundo MANKIW: “ A expressão incidência tributária se refere a como o ônus tributário é distribuído entre as varias pessoas que formam a economia." Ibid. p. 117 


\section{CAPÍTULO VI}

\section{Guerra Fiscal, Incentivos e Benefícios}

A guerra fiscal refere-se à disputa entre os entes federativos para atraírem aos seus territórios agentes econômicos, mediante a concessão de incentivos fiscais. Em matéria de ICMS esse tema possui mais fácil visualização. A Constituição Federal já ciente de tais disputas dispôs a necessidade de lei complementar que regulasse a forma pela qual isenções, incentivos e e benefícios fiscais deveriam, ser concedidos (art. 155, $\S 2^{\circ}$, XII, g CF). No entanto, não adveio tal lei complementar de modo que, assim como previsto no artigo $34 \S 8^{\circ}$ dos Atos das Disposições Constitucionais Transitórias - ADCT ${ }^{99}$, manteve-se a forma do convênio definida pela Lei Complementar no 24 de 7 de janeiro de 1975.

Através do convênio exige-se a decisão unanime dos Estados para concessão de benefícios atinentes ao ICMS ${ }^{100}$, tal unanimidade pressupõe a ausência de disputa, e assim, que uma decisão estatal seja deliberada tomando a analise de todos os estados membros. Dessa forma, o que se espera é a inocorrência de grandes impactos ou desequilíbrios concorrenciais, até porque se lhe fosse extremamente gravoso o estado prejudicado não aprovaria o convênio.

Ocorre que sabendo que nem sempre os Estados submetem-se a tal deliberação e acabam por elaborar autonomamente leis concessivas de benefícios atinentes ao ICMS sendo alvo de constantes ações diretas de inconstitucionalidade .

\footnotetext{
99 "Art. $34 \S 8^{\circ} \mathrm{Se}$, no prazo de sessenta dias contados da promulgação da Constituição, não for editada a lei complementar necessária à instituição do imposto de que trata o art. 155, I, "b", os Estados e o Distrito Federal, mediante convênio celebrado nos termos da Lei Complementar no 24 , de 7 de janeiro de 1975, fixarão normas para regular provisoriamente a matéria."
}

100 “Art. $2^{\circ} \S 2^{\circ}$ - A concessão de benefícios dependerá sempre de decisão unânime dos Estados representados; a sua revogação total ou parcial dependerá de aprovação de quatro quintos, pelo menos, dos representantes presentes." Lei Complementar no 24/1975" 
Nesse sentido menciona-se a Ação Direta de Inconstitucionalidade $\mathrm{n}^{\circ}$ 4276, na qual ponderou-se que além da exoneração fiscal corresponder à derivação do poder de tributar e em regra não haver impedimentos no que tange a definição de hipóteses de benefícios fiscais, tal matéria no que tange ao ICMS, deve observar a particularidade constitucional, qual seja, a forma de convênio a fim de que será preservado o equilíbrio na tributação ${ }^{101}$, seguindo assim ementada:

"AÇÃO DIRETA DE INCONSTITUCIONALIDADE. TRIBUTÁRIO. ISENÇÃO FISCAL. ICMS. LEI COMPLEMENTAR ESTADUAL. EXIGÊNCIA CONSTITUCIONAL DE CONVÊNIO INTERESTADUAL (CF, ART. $155, \S 20$, XII, 'g'). DESCUMPRIMENTO. RISCO DE DESEQUILÍBRIO DO PACTO FEDERATIVO. GUERRA FISCAL. INCONSTITUCIONALIDADE FORMAL. CONCESSÃO DE ISENÇÃO À OPERAÇ̃̃̃O DE AQUISIÇ̃̃O DE AUTOMÓVEIS POR OFICIAIS DE JUSTIÇA ESTADUAIS. VIOLAÇÃO AO PRINCÍPIO DA ISONOMIA TRIBUTÁRIA (CF, ART. 150, II). DISTINÇ̃̃O DE TRATAMENTO EM RAZÃO DE FUNÇ̃̃O SEM QUALQUER BASE RAZOÁVEL A JUSTIFICAR O DISCRIMEN. INCONSTITUCIONALIDADE MATERIAL. PROCEDÊNCIA DO PEDIDO.

1. O pacto federativo reclama, para a preservação do equilíbrio horizontal na tributação, a prévia deliberação dos Estados-membros para a concessão de benefícios fiscais relativamente ao ICMS, na forma prevista no art. 155, § 2o, XII, 'g', da Constituição e como disciplinado pela Lei Complementar no $24 / 75$, recepcionada pela atual ordem constitucional.

2. In casu, padece de inconstitucionalidade formal a Lei Complementar no 358/09 do Estado do Mato Grosso, porquanto concessiva de isenção fiscal, no que concerne ao ICMS, para as operações de aquisição de automóveis por oficiais de justiça estaduais sem o necessário amparo em convênio interestadual, caracterizando hipótese típica de guerra fiscal em desarmonia com a Constituição Federal de 1988.

3. A isonomia tributária (CF, art. 150, II) torna inválidas as distinções entre contribuintes "em razão de ocupação profissional ou função por eles exercida", máxime nas hipóteses nas quais, sem qualquer base axiológica no postulado da razoabilidade, engendra-se tratamento discriminatório em benefício da categoria dos oficiais de justiça estaduais.

\footnotetext{
${ }^{101}$ O Ministro Relator Luiz Fux dispôs que: “A Constituição Federal instituiu regime particular a respeito do modo como tais exonerações fiscais devem ser colocadas em prática no campo do ICMS, exigindo, para que isso ocorra, a existência de deliberação entre os Estados-membros, nos termos de disciplina por lei complementar, tal como proclamado pelo art. $155, \S 2^{\circ}$, XII, ' $\mathrm{g}$ ', da CF.A finalidade por detrás da referida exigência consiste na preservação do equilíbrio horizontal na tributação, dada a relevância do regime do ICMS para a manutenção da harmonia do pacto federativo (TORRES, Ricardo Lobo. Tratado de direito constitucional financeiro e tributário, vol. IV, Rio de Janeiro: Ed. Renovar, 2007, p. 295; PYRRHO, Sérgio. Soberania, ICMS e isenções - os convênios e os tratados internacionais, Rio de Janeiro: Ed. Lumen Juris, 2008, p. 32).”
} 
4. Ação direta de inconstitucionalidade julgada procedente.(ADI 4.276, relator Luiz Fux, DJ 18.9.2014).” (grifo nosso)

Da mesma forma a Ação Direta de Inconstitucionalidade no 3796 PR:

"Ação direta de inconstitucionalidade.

2. Lei n. 15.054/2006 do Estado do Paraná que restabelece benefícios fiscais no âmbito dos programas Bom Emprego, Paraná Mais Emprego e Desenvolvimento Econômico, Tecnológico e Social do Paraná (PRODEPAR). 3. Vício de iniciativa. Matéria tributária. Inexistência de iniciativa exclusiva do Chefe do Executivo. Precedentes.

4. Violação do art. 14 da Lei de Responsabilidade Fiscal. Afronta ao art. 163, I, da Constituição Federal. Impossibilidade de adoção de dispositivos infraconstitucionais como parâmetro de controle. Precedentes.

5. Inexistência de violação à isonomia.

6. Causa de pedir aberta. Ofensa à alínea "g" do inciso XII do § 20 do art. 155 da Constituição ("guerra fiscal".) Concessão unilateral de benefício fiscal no âmbito do ICMS. Inconstitucionalidade. Precedentes.

7. Ação direta de inconstitucionalidade julgada procedente. (ADI 3796, relator Min. Gilmar Mendes, DJ. 01.08.2017)” (grifo nosso)

Bem como a Ação Direta de Inconstitucionalidade n 2663 RS102:

“AÇÃO DIRETA DE INCONSTITUCIONALIDADE. DIREITO CONSTITUCIONAL E TRIBUTÁRIO. LEI ESTADUAL. CONCESSÃO DE BOLSAS DE ESTUDO A PROFESSORES. COMPETÊNCIA LEGISLATIVA CONCORRENTE (ART. 24, IX, DA CRFB/88). COMPREENSÃO AXIOLÓGICA E PLURALISTA DO FEDERALISMO BRASILEIRO (ART. 1o, V, DA CRFB/88). NECESSIDADE DE PRESTIGIAR INICIATIVAS NORMATIVAS REGIONAIS E LOCAIS SEMPRE QUE NÃO HOUVER EXPRESSA E CATEGÓRICA INTERDIÇÃO CONSTITUCIONAL. EXERCÍCIO REGULAR DA COMPETÊNCIA LEGISLATIVA PELO ESTADO DO RIO GRANDE DO SUL. INSTITUIÇÃO UNILATERAL DE BENEFÍCIO FISCAL RELATIVO AO ICMS. EXIGÊNCIA CONSTITUCIONAL DE PRÉVIO CONVÊNIO INTERESTADUAL (ART. $155, \S 20, X I I$, ' $g$ ', da CRFB/88). DESCUMPRIMENTO. RISCO DE DESEQUILÍBRIO DO PACTO FEDERATIVO. GUERRA FISCAL. PROCEDÊNCIA PARCIAL DO PEDIDO, COM EFEITOS EX NUNC.

1. O princípio federativo reclama o abandono de qualquer leitura inflacionada e centralizadora das competências normativas da União, bem como sugere novas searas normativas que possam ser trilhadas pelos Estados, Municípios e pelo Distrito Federal.

2. A prospective overruling, antídoto ao engessamento do pensamento jurídico, possibilita ao Supremo Tribunal Federal rever sua postura prima facie em casos de litígios constitucionais em matéria de competência legislativa, viabilizando o

\footnotetext{
$102 \mathrm{Na}$ mencionada ação, foi ponderado que os prejuízos advindos da guerra fiscal afetam não só o equilíbrio tributário, como em última analise o próprio federalismo. Nesse sentido o Ministro Relator Luiz Fui argumentou no voto que: "Com efeito, se fosse lícito a cada ente federativo regional a instituição de exonerações fiscais de forma independente, o resultado que daí adviria seria a cognominada guerra fiscal, com a busca irrefreável pela redução da carga tributária em cada Estado, de forma a atrair empreendimentos e capital para o respectivo território, em prejuízo, em última análise, para a própria forma de estado federalista e seus consectários fiscais." (STF, ADI2.663, Relator: Min. Luiz Fux, Brasília DJ. 22.08.2017)"
} 
prestígio das iniciativas regionais e locais, ressalvadas as hipóteses de ofensa expressa e inequívoca de norma da Constituição de 1988.

3. A competência legislativa de Estado-membro para dispor sobre educação e ensino (art. 24, IX, da CRFB/88) autoriza a fixação, por lei local, da possibilidade de concessão de bolsas de estudo a professores, em aprimoramento do sistema regional de ensino.

4. O pacto federativo reclama, para a preservação do equilíbrio horizontal na tributação, a prévia deliberação dos Estados-membros para a concessão de benefícios fiscais relativamente ao ICMS, na forma prevista no art. 155, § 2o, XII, 'g', da Constituição e como disciplinado pela Lei Complementar no $24 / 75$, recepcionada pela atual ordem constitucional.

5. In casu, padece de inconstitucionalidade o art. 30 da Lei no 11.743/02, do Estado do Rio Grande do Sul, porquanto concessiva de benefício fiscal de ICMS sem antecedente deliberação dos Estados e do Distrito Federal, caracterizando hipótese típica de exoneração conducente à guerra fiscal em desarmonia com a Constituição Federal de 1988.

6. Pedido de declaração de inconstitucionalidade julgado parcialmente procedente, conferindo à decisão efeitos ex nunc, a partir da publicação da ata deste julgamento (art. 27 da Lei no 9.868/99). (ADI2.663, Relator: Min. Luiz Fux, DJ. 22.08.2017)"

Importante dizer que em razão dessas violações à Lei Complementar 24 de 1975, foi aprovada a Lei Complementar $n^{\circ} 160$ de 7 de agosto de 2017, que objetivou reduzir a insegurança jurídica do contribuinte. Para tanto tece previsões no sentido de que, mesmo quando haja a inobservância da exigência do art. $155, \S 2^{\circ}$, XII, g CF na concessão de benefícios físcais ou financeiro-fiscais seja possível aprovar remissão dos decorrentes créditos tributários, constituídos ou não, bem como a sua reinstituição (Art. $1^{\circ}$, II) exigindo-se para tanto o quorum de " $2 / 3$ (dois terços) das unidades federadas" (art. $\left.2^{\circ}, \mathrm{I}\right)$; e "1/3 (um terço) das unidades federadas integrantes de cada uma das 5 (cinco) regiões do País." (art. $\left.2^{\circ}, \mathrm{II}\right)$

Fato é que, presente a guerra fiscal acaba-se por ter o cenário propício ao desenvolvimento de praticas anticoncorrenciais. Assim, tem-se um fluxo migratório de sociedades empresárias, uma redução dos preços com viés anticompetitivo visando a eliminação de concorrência, domínio de mercado e quiçá emergencia de barreiras a novos players. 
Tal "ameaça" ao equilíbrio concorrencial já foi alvo de consulta perante o CADE, através da Consulta $\mathrm{n}^{\circ} 38$ de 1999, que será objeto do próximo capitulo, na qual se indagou a possibilidade de distorção concorrencial e ampliação de vantagem competitiva derivada dos benefícios fiscais. 


\section{CAPÍTULO VII}

\section{Tributação e Concorrência no CADE}

Apesar da escassez de decisões no Conselho Administrativo de Defesa Econômica que analisem questões tributarias como fator de desequilíbrios concorrenciais pode-se mencionar a Consulta $n^{\circ}$ 0038/99, solicitada pelo Pensamento Nacional das Bases Empresariais - PNBE para que o CADE se manifesta-se acerca da repercussão da guerra fiscal na livre concorrência. O consulente afirmara que a guerra fiscal vem sendo utilizada pelas concorrentes com forma de distorção concorrencial e ampliação da vantagem competitiva, vez que se valem dos incentivos para reduzirem desproporcionalmente os preços, criando com isso barreira de entrada a novas empresas, bem como desequilíbrio face aos demais integrantes do mercado.

No voto proferido pelo Conselheiro Relator Marcelo Calliari reconhece-se a influência da tributação no sistema concorrencial, seja na alocação de recursos, seja na subsistência de cenário apto à praticas anticoncorrenciais (como por exemplo preços predatórios), bem como que a guerra fiscal representa fator de vantagem competitiva a determinados agentes ocasionando consequentemente um distúrbio concorrencial. Nestes termos concluiu-se que:

“1) A concessão de incentivos fiscais ou financeiro-fiscais possui o mesmo efeito para a empresa e para o mercado. Ambos esse tipos importarão na redução artificial do montante de imposto a pagar, gerando os mesmos efeitos seja para a empresa favorecida seja para os concorrentes e o mercado.

2) Benefícios concedidos no âmbito da "guerra fiscal", como visto numericamente, conferem vantagem dramática às empresas afetadas, podendo aumentar lucros em várias centenas de pontos percentuais.

3) Esse brutal favorecimento desnivela o campo em que se desenrola a dinâmica econômica, gerando diversos efeitos para a concorrência e o bem estar da coletividade, entre os quais:

a) Retira o estímulo ao aumento constante do nível geral de eficiência da economia, permitindo uso menos eficiente de recursos e afetando negativamente a capacidade de geração de riquezas do país. 
.b) Protege as empresas incentivadas da concorrência, mascarando seu desempenho, permitindo que mantenham práticas ineficientes e desestimulando melhorias na produção ou inovação.

.c) Permite que empresas incentivadas, ainda que auferindo lucros, possam "predatoriamente" eliminar do mercado suas concorrentes não favorecidas, mesmo que estas sejam mais eficientes e inovadoras, em função do enorme colchão protetor de que dispõem.

.d) Prejudica as demais empresas que, independentemente de sua capacidade, terão maiores dificuldades na luta pelo mercado, gerando com isso mais desincentivo à melhoria de eficiência e inovação.

.e) Gera incerteza e insegurança para o planejamento e tomada de decisão empresarial, dado que qualquer cálculo feito pode ser drasticamente alterado -e qualquer inversão realizada pode ser drasticamente inviabilizada com a concessão de um novo incentivo.

.f) Desestimula, por tudo isso, a realização de investimentos tanto novos quanto a expansão de atividade em andamento.

É mais do que evidente, assim, que a guerra fiscal tem efeito altamente prejudicial à concorrência e danoso ao bem estar da coletividade.

.4) A Constituição apresenta uma diversidade de objetivos e princípios que devem ser aplicados da forma mais harmônica possível. A livre concorrência e o bem estar geral constituem alguns deles, a ser compatibilizados com outros, igualmente legítimos, como o da redução das desigualdades regionais.

.5) A decisão de conceder incentivos é prevista e aceita na Constituição, desde que determinada de formas específicas, as quais, ao menos formalmente, asseguraram que órgão concedente (a União ou os Estados por unanimidade no CONFAZ) sopese os diferentes interesses e princípios envolvidos, determine quais os incentivos, quais as regiões beneficiadas e montantes adequados de forma a avançar ao máximo o princípio da redução das desigualdades regionais e afastando o mínimo necessário o outro.

.6) Segundo o PNBE, os incentivos e benefícios no Brasil são concedidos à revelia das normas descritas acima, de forma que não se assegura a compatibilização constitucional mencionada, potencialmente violando o princípio da livre concorrência além do que seria justificável. Geram todos os efeitos negativos referidos acima, particularmente o de provocar insegurança, inibindo ou desestimulando ainda mais os investimentos, dado que a concessão imprevisível de incentivos altera radicalmente o mercado e pode mesmo tornar inviáveis inversões feitas após cuidadoso planejamento. Nesse sentido, o mero cumprimento da legislação atual já traria significativos benefícios para a coletividade.

.7) Propostas que reduzam a possibilidade de guerra fiscal, ou que disciplinem a concessão de incentivos de forma previsível e segundo um sistema racional (definido pelas autoridades constitucionalmente competentes) podem contribuir para atenuar os danos hoje provocados por esta prática para o bem estar social e merecem pelas autoridades responsáveis uma cuidadosa atenção.

.8) Dada a patente relação do tema com a defesa da concorrência, o CADE permanece passível de engajamento no debate, dentro evidentemente da sua esfera de competência legal, como evidenciada pela presente Consulta. 


\section{(grifos nossos)}

Assim, percebe-se não só a valorização dos preceitos constitucionais da livre iniciativa e da livre concorrência como também da busca pelo equilíbrio do mercado de modo a propiciar o atendimento ao bem maior que seria o interesse da coletividade.

Nesses moldes, retoma-se a instrumentalização do direito concorrencial, isto é, ele não tem por finalidade a proteção do mercado em si, e sim da estrutura econômica como um todo, considerada como sistema multipolarizado - atendendo diversos núcleos de interesse. Do mesmo modo, reconhece-se a tributação como fator de influencia na ordem concorrencial ao passo que se admite a sua instrumentalidade na aquisição de vantagens competitivas.

Já no Processo Administrativo n.o 08000.004542/97- 13 que teve por representante o Sindicato do Comércio Varejista de Produtos Farmacêuticos de Florianópolis em face do Serviço Social da Indústria SESI visto que este estaria praticando preços abaixo do preço de mercado, segundo o sindicato, em decorrência de benefícios fiscais. Apesar do CADE ter entendido pela não ocorrência de preços predatórios é relevante a fundamentação do Conselheiro Thompson Andrade no que tange a possibilidade do benefício tributário ensejar violação a ordem concorrencial. Nesse sentido:

“(...) O fato do SESI não recolher outros tributos, como Cofins e IRPJ, constitui-se, indubitavelmente, em vantagem competitiva auferida pelas farmácias do SESI. Entretanto, esta vantagem é conferida pela lei, cabendo ao CADE a investigação sobre os prováveis danos à concorrência e aos consumidores, decorrentes ou não desta vantagem, provocados por meio de condutas ofensivas à ordem econômica, como por exemplo, a pratica de preços predatórios, objetivando o domínio de mercado.

Para caracterizar a infração caberia a demonstração de que o SESI estaria se beneficiando das isenções tributarias para praticar preços abaixo do custo, com 
o fito de eliminar a concorrência, vindo futuramente a monopolizar o mercado."103104

Na Consulta $n^{\circ}$ 08700.002380/2006-35 formulada pela Philips da Amazônia Indústria Eletrônica Ltda., Panasonic do Brasil Ltda., Sony do Brasil Ltda., e Sem Toshiba S/A, ao Conselho Administrativo de Defesa Econômica, objetivou-se indagar se haveria infração à ordem econômica mediante a tratamento desigual concedido pelo Estado do Amazonas através das Leis $2.390 / 96$ e a Lei $1.938 / 89$. Basicamente, a primeira concedida a aqueles que estão ingressando na fabricação de televisores na região a restituição do equivalente a $100 \%$ do ICMS, observados níveis de produção. Enquanto isso, as empresas já inseridas no mercado estavam sob a abrangência da Lei 1.938/89 que garantia a restituição apenas do equivalente a 50\%. Apesar da edição de nova Lei, a n 2.86/03 objetivando encerrar o tratamento desigual, a mesma acabou por admitir a possibilidade de manutenção do regime da lei 2.390/96 às empresas por ela já beneficiadas, frustando-se assim sua finalidade e perpetuando o tratamento desigual.

No presente caso, o CADE se manifestou pelo arquivamento visto não se tratar a consulta de questionamento abstrato e ainda que tal tratamento diferenciado poderia sustentar-se na existência de desigualdades entre os players, e assim, teria um viés pró concorrência, já que reduzindo barreiras de entrada. Rodrigo Maito da Silveira profere critica a tal desfecho formal já que:

"Respeitadas as questões prejudicial e formais, entendemos que havia convictos de o CADE ter se aprofundado na questão suscitada, a partir de um processo investigativo mais abrangente.

Isso porque, conforme sustentamos anteriormente, é necessário que se identifique a razão pela qual seria valido o tratamento tributário diferenciado.

\footnotetext{
103 SILVEIRA, Rodrigo Maito da. Op. cit. p. 170

${ }^{104}$ Em sentido similar foi julgado o Processo Administrativo 08012.000668/98-06.
} 
Na hipótese de tal razão não ser apurada, é perfeitamente possível que, a partir da constatação de exercício abusivo de posição dominante, aumento arbitrário de lucros, domínio de mercado relevante ou ato lesivo à livre concorrência e à livre inciativa, que o agente seja condenado por pratica lesiva à ordem econômica.” 105

Por ocasião da Averiguação Preliminar n.o 08000.013472/95-51 o CADE enfrentou a vantagem competitiva decorrente de imunidade tributária. No caso houve uma denuncia ao Ministério Publico da Organização Hoteleira Fonte Colina Verde Ltda., em face do SENAC Serviço Nacional de Aprendizagem comercial na qualidade de proprietárioadministrador do Grand Hotel-Escola Águas de São Pedro. Isso porque acusou-se este de valer-se de imunidade decorrente do artigo 150, IV, c da $\mathrm{CF} / 88$ de que goza o proprietário-administrador para obter vantagem competitiva e com isso praticar preços abaixo do nível de mercado, almejando com isso a eliminação de concorrência.

O Conselho Administrativo decidiu pela ausência de infração à concorrência, seja porque a acusada não detinha poder de mercado que the permitisse a pratica de preços predatórios, tampouco pela inexistência de barreiras de entrada. Além disso, constatou-se que a acusada não detinha condições de absorção da demanda hoteleira de modo a eliminar seus concorrentes. Assim, arquivou-se a averiguação.

Percebe-se que mesmo a ausência de enfrentamento direto do CADE sobre os impactos da tributação na ordem concorrencial, as decisões abordadas denotaram o reconhecimento desses potenciais impactos. De modo que, tem-se a tributação como veiculo de interferência na ordem econômica. 


\section{CONCLUSÃO}

Face a todo o exposto é possível afirmar que a carga tributária tem reflexos na ordem econômica e dessa forma pode ser utilizada como veículo de infração à concorrência. Reconhece-se assim, um teor indutivo da tributação, influenciando a alocação de recursos e criando incentivos a determinadas condutas.

Por outro lado, viu-se que face aos custos da tributação ao mercado o próprio agente busca artifícios para redução da carga tributária, valendo-se de instrumentos como o planejamento tributário - tido como expressão da liberdade do contribuinte, já que não é compelido à adoção de via mais onerosa, pelo contrário.

Percebeu-se que em regra, o planejamento tributário é via lícita, tratando-se de elisão fiscal, valendo-se o eventual contribuinte de brechas na própria lei fiscal para despender menores gastos. Contudo, não passou desapercebida a possibilidade de o planejamento tributário demonstrar caráter abusivo quando da sua utilização distorcida seja no plano nacional como também no plano internacional - neste, através da figura denominada treaty shopping e a possibilidade de estruturações elaboradas a fim de se atingir uma "dupla não tributação".

Do mesmo modo, se se reconhece o caráter indutivo da tributação, seus efeitos devem ser levados em conta pelos entes tributantes. Até mesmo como forma de planificar e orientar a função estatal de implementação de políticas públicas.

Nessa esteira, retoma-se a instrumentalização do direito concorrencial e a compreensão da concorrência como valor em si, objeto de proteção, bem como a necessidade de um olhar multipolarizado, demandando-se não só a analise dos impactos tributários, como também de quais medidas conduzem a um melhor atendimento do bem estar social. Isto 
é: deve ser levado em conta se a interferência no mercado acarretará efeitos mais benéficos ou maléficos que aqueles decorrentes do investimento do produto da arrecadação fiscal.

Além disso, abordou-se a neutralidade tributária se entendida como ausência de reflexos na ordem econômica é utópica e idealista. Para tanto, o princípio da neutralidade tributária deve ser entendido sob a acepção restrita de modo que implique a observância dos reflexos da tributação a fim de evitar desequilíbrios concorrenciais bem como a sua utilização como instrumento de correção de tais desequilíbrios, em atendimento à livre concorrência.

Necessário ainda reiterar a afirmação de que o apesar do artigo 146A da Constituição Federal reconhecer a possibilidade da tributação ocasionar desequilíbrios da concorrência tal dispositivo permite apenas e tão somente a edição de lei completar para definir critérios especiais de tributação para prevenir desequilíbrios. $\mathrm{O}$ que se quer dizer é que o referido diploma não autoriza a edição de normas com o intuito de reprimir distorções concorrenciais, visto ser função precípua do Sistema Brasileiro de Defesa da Concorrência a repressão de abusos. Isso porque além do artigo gozar de caráter preventivo, a utilização da tributação como forma de intervenção nas estruturas de mercado pode se dar via extrafiscalidade.

Abordou-se ainda os reflexos oriundos da guerra fiscal, da concessão de incentivos e benefícios fiscais de modo que podem ensejar, como se viu, não só o arcabouço para a pratica de preços predatórios como também como fator de dominação de mercado e ampliação de vantagem competitiva. O Supremo Tribunal Federal inclusive reconheceu a necessidade de avaliação de efeitos colaterais decorrentes da imunidade 
tributária, admitindo-os até mesmo como justificativa do afastamento em tese de tal privilégio.

E por fim, na seara do tribunal administrativo analisou-se raras ocasiões em que houve a apreciação da matéria tributaria como fator de influencia no direito concorrencial. Viu-se que, apesar da consideração tangencial do tema, caracterizou-se o reconhecimento da potencialidade da tributação como fator de distorção concorrencial. 


\section{BIBLIOGRAFIA}

AMARO, Luciano. Direito tributário brasileiro. 21. ed. - São Paulo: Saraiva, 2016. 544p.

ASQUINI, Alberto. Perfis da Empresa. Traduzido por: Fábio Konder Comparato. Revista de Direito Mercantil vol.104, out-dez/1996, págs. 109-126

ATALIBA, Geraldo. Hipótese de Incidência Tributária. $5^{\mathrm{a}}$ ed. $8^{\mathrm{a}}$ tiragem..São Paulo: Malheiros, 1992. 182p.

BALEEIRO, Aliomar. Uma introdução à Ciência das Finanças. $19^{\mathrm{a}}$ ed. revista e atualizada por Hugo de Brito Machado Segundo. Rio de Janeiro: Forense, 2015. 688p.

Direito tributário brasileiro. $13^{\circ}$ ed. Atualizada por Misabel Abreu Machado Derzi. Rio de Janeiro: Forense, 2015. 1584p.

BARBOSA, Pedro Marcos Nunes. O Estabelecimento Comercial Virtual: Universalidade, Direito à Identidade e Tutela Através de Direito Real. São Paulo, 2016. 302p. Tese de Doutorado em Direito Comercial - Faculdade de Direito Universidade de São Paulo.

BECKER, Alfredo Augusto. Teoria Geral do Direito Tributário. $2^{\mathrm{a}}$ ed. São Paulo: Saraiva, 1972. 621p.

BENKLER, Yochai. The wealth of networks : how social production transforms markets and freedom. 2006. Disponível em: <http:// www.benkler.org/Benkler_Wealth_Of_- Networks.pdf $>$ Acesso em: 05 de junho de 2017.

BERCOVICI, Gilberto. Constituição econômica e desenvolvimento : uma leitura a partir da Constituição de 1988. São Paulo: Malheiros, 2005. 190p. 
BINENBOJM, Gustavo. Uma teoria do direito administrativo: direitos fundamentais, democracia e constitucionalização. 3a ed. revista e atualizada. Rio de Janeiro: Renovar, 2014. 358p.

BRAZUNA, José Luis Ribeiro. Defesa da Concorrência e Tributação - à luz do Artigo 146-A da Constituição - Série Doutrina Tributária Vol. II - São Paulo: Quartier Latin, 2009. 295p.

CADE, Consulta $n^{\circ}$ 08700.002380/2006-35, Relator: Conselheiro Luís Fernando Rigato Vasconcellos, Brasília, 13 jun 2007.

CADE, Consulta $\mathrm{n}^{\circ}$ 0038/99, Relator: Conselheiro Marcelo Calliari, Brasília, 29 jul 1999.

CADE, Processo Administrativo n.o 08000.004542/97- 13 Relator: Conselheiro Thompson Andrade, Brasília, 29 nov 2000.

CADE, Averiguação Preliminar n.o 08000.013472/95-51,Relator: Conselheira Lucia Helena Salgado e Silva, Brasília, 29 jul 2004.

CARVALHO FILHO, José dos Santos. Manual de direito administrativo 28 ed.rev.,ampl. e atual. até 21-12-2014. São Paulo: Atlas, 2015. 1376p.

COÊLHO, Sacha Calmon Navarro. Teoria da Evasão e da Elisão em Matéria Tributária. Disponível em: http://49ga9f10blgreaqid23bdv7swpengine.netdna-ssl.com/wp-content/uploads/2010/12/Evasão-e-ElisãoDialética.pdf $>$ Acesso em: 20 out. 2017.

FORGIONI, Paula A. Os Fundamentos do Antitruste. 8.ed.rev., atual. e ampl. São Paulo: Editora Revista dos Tribunais, 2015. 492p.

Direito concorrencial e restrições verticais. São Paulo: Editora Revista dos Tribunais, 2007. 320p.

GABAN, Eduardo Molan. DOMINGUES, Juliana Oliveira. DIREITO ANTITRUSTE. 4.ed. São Paulo: Saraiva, 2016. 574p. 
GESNER, Oliveira; RODAS, João Grandino. - Direito e Economia da Concorrência. 2a ed. rev. e atual. São Paulo: Editora Revista dos Tribunais, 2013. 495p.

GRAU, Eros Roberto. A ordem econômica na constituição de 1988: interpretação e crítica. 17a ed. atual. São Paulo: Malheiros, 2015. 384p.

HESSE, Konrad. A FORÇA NORMATIVA DA CONSTITUIÇÃO. Traduzido por: Gilmar Ferreira Mendes. Porto Alegre: safE.

HUETE, Miguel Ángel Sánchez. El Carácter Fundamental del Deber de Contribuir: el Derecho y la Ética de las Relaciones Tributarias. Direito, Estado e Sociedade: Revista do Departamento de Direito da PUC-Rio. Rio de Janeiro n.50, p. 179 a 207, jan/jun 2017 Disponível em < $\underline{\text { http:// }}$ www.jur.puc-rio.br/revistades/index.php/revistades/article/view/ 934/464>Acesso em: outubro 2017

IRTI, Natalino - L'ordine Giuridico del Mercato. 3a ed. Roma: Laterza. 1998. 155p.

LASSALE, Ferdinand. O que é uma Constituição?. Traduzido por: Walter Stönner. São Paulo: Edições e Publicações Brasil, 1993.

MANKIW, N. Gregory. Introdução à economia - Tradução: Allan Vidigal Hastings, Elisete Paes e Lima, Ez2 Translate; revisão técnica Manuef1 José Nunes Pinto. São Paulo: Cengage Learning, 2013.

MENDONÇA, José Vicente Santos de. Direito constitucional econômico: a intervenção do Estado na economia à luz da razão pública e do pragmatismo. Belo Horizonte: Fórum, 2014. 490p.

MOREIRA, André Mendes. ELISÃO E EVASÃO FISCAL - LIMITES AO PLANEJAMENTO TRIBUTÁRIO. Disponível em < http:// sachacalmon.wpengine.netdna-cdn.com/wp-content/uploads/2010/10/O- 
Planejamento-Tributario-sob-a-otica-do-Codigo-Tributario-Nacional.pdf $>$ Acesso em: out $/ 2017$.

NOGUEIRA, Vinicius Alberto Rossi. Direito tributário e livre concorrência: da interpretação e aplicação do artigo 146-A da Constituição Federal. São Paulo, 2014. 128p. Dissertação de Mestrado . Faculdade de Direito da Universidade de São Paulo

PERLINGIERI, Pietro. Perfis do Direito Civil: Introdução ao Direito Civil Constitucional. tradução de: Maria Cristina de Cinco. 3a ed.rev. e ampl. Rio de Janeiro: Renovar, 2002.369p.

POSNER, Richard A.; PARISI, Francesco. Economic foundations of private law. Massa- chusetts: Edward Elgar Publishing, 2003.

ROSA JÚNIOR, Luiz Emygdio F. da. Manual de direito tributário - 2. e. revista e atualizada - Rio de Janeiro: Renovar, 2012. 843p.

SAlOMÃo FILHO, Calixto. Direito Concorrencial - As Condutas. 1a ed. 2a tiragem. São Paulo: Malheiros, 2007. 334p.

SCHUMPETER, Joseph. Capitalismo, Socialismo e Democracia. Editado por George Allen e Unwin Ltd., traduzido por Ruy Jungmann. Rio de Janeiro: Fundo de Cultura. 1961. 512p.

SOUZA NETO, Claudio Pereira de; SARMENTO, Daniel. Direito constitucional: teoria, história e métodos de trabalho. $2^{\mathrm{a}}$ ed., 2. reimpr. Belo Horizonte: Fórum, 2016. 624p.

STF, ADI2.663, Rel.Min. Luiz Fux, Brasília, 22. ago 2017

STF, ADI 3796, Rel. Min. Gilmar Mendes, Brasília, 01 ago 2017

STF, ADI 4.276, Rel. Luiz Fux, Brasília, 18 set 2014 
STF, Recuso Extraordinário 599.176 PR Rel. Min. Joaquim Barbosa, Brasília, 05 jun 2014

STF, Recurso Extraordinário 253.472 SP, Rel. Min. Marco Aurélio, 25 ago 2010

STF, RE 406.955 AgR, Rel. Min. Joaquim Barbosa, Brasília, 4 out 2011.

TORRES, Ricardo Lobo. Curso de direito financeiro e tributário - $17^{\mathrm{a}}$ ed. Rio de Janeiro: Renovar. 2010. 470p.

A idéia de liberdade no estado patrimonial e no estado fiscal. Rio de Janeiro: Renovar, 1991. 200p.

Planejamento tributário: elisão abusiva e evasão fiscal. $2^{\mathrm{a}}$ ed. Rio de Janeiro: Elsevier, 2013.

Tribunal Regional Federal -4ª Região -AG:44424 RS 2004.04.01.044424-0, Rel. Dirceu de Almeida Soares, Porto Alegre, 30 nov 2004. 